\title{
The Information Content of Quarterly Earnings in Syndicated Bank Loan Prices
}

\author{
Linda Allen \\ Professor of Finance \\ Zicklin School of Business, Baruch College, CUNY \\ Linda_Allen@baruch.cuny.edu \\ Hongtao Guo* \\ Assistant Professor of Accountancy \\ Zicklin School of Business, Baruch College, CUNY \\ Hongtao_Guo@baruch.cuny.edu \\ Joseph Weintrop \\ Stan Ross Professor of Accountancy \\ Zicklin School of Business, Baruch College, CUNY \\ Joseph_Weintrop@baruch.cuny.edu
}

August 29, 2004.

\footnotetext{
*Contact Author: Department of Accountancy, Zicklin School of Business, Baruch College, CUNY, One Bernard Baruch Way, New York, NY 10010. Phone: 646-312-3207, Fax: 646-312-3161, E-mail: hongtao_guo@baruch.cuny.edu

Financial Support from the KPMG, the University of Illinois Business Measurement Research Program and PSC-CUNY is gratefully acknowledged. We thank Itzhak Venezia for helpful comments. All errors remain our responsibility.
} 


\title{
The Information Content of Quarterly Earnings in Syndicated Bank Loan Prices
}

\begin{abstract}
$\underline{\text { Abstract }}$
We examine the information content of quarterly earnings announcements in the syndicated bank loan market, a hybrid public/private debt market that is exclusively comprised of informed institutional participants. In contrast to the literature on equity price reactions to earnings announcements, we find that bank loan returns experience no significant response on earnings announcement dates. However, we do find significant price movements in the secondary loan market four weeks prior to earnings announcement dates, around the time of the monthly covenant reports to members of the syndicate. Moreover, we find that the information content in syndicated bank loan prices is most pronounced for borrowers with predominantly intangible assets that experience declining earnings. Thus, we find evidence that when earnings announcements convey relevant information about the borrowing firm (i.e., for informationally opaque firms with declining creditworthiness), the syndicated bank loan market expeditiously incorporates that information into prices.
\end{abstract}

\section{JEL Classifications: G14, M41}

Keywords: earnings announcements, syndicated bank loans 


\section{Introduction}

In this paper, we examine the information content in earnings as reflected in changes in the prices to the holders of syndicated bank loans. We find no evidence that, at the time of the release of the earnings, there is any change in these private debt holders' perception of future cash flows, as reflected in a change in secondary bank loan prices at the time of the quarterly earnings announcements. However, when we examine the change in secondary bank loan prices from a period starting five weeks before the quarterly earnings announcement, around the time of the monthly covenant reports to all members of the syndicate, we find that there is a statistically significant decline in prices for those firms that are about to announce a decline in earnings. There is no similar effect for firms that are about to announce earnings increases. We interpret this finding to be consistent with the belief that holders of bank loans are able to more closely monitor the financial activities of the firm and so any information that might adversely affect the prospects of future loan repayments is expeditiously reflected in loan prices in the secondary bank loan market. Thus, participants in the syndicated bank loan market need not wait for the release of quarterly earnings in order to incorporate the information contained therein into loan prices.

The information content associated with the release of annual and quarterly earnings announcements has been extensively studied (see Bernard, 1989 and Kothari, 2001 for comprehensive reviews of this topic). The evidence is overwhelming that equity holders use earnings announcements to update their perceptions about the future cash flows of the firm. For a variety of institutional reasons, namely the lack of publicly available data and infrequency of trades, there is much less empirical evidence examining 
the impact of earnings announcements on debt prices. Even though debt makes up a substantial part of a firm's capital structure, the difficulties in getting unique prices and infrequent trading have limited the number of empirical studies. ${ }^{1}$

Within the debt market, we loosely categorize debt into those issues where the Securities and Exchange Commission mandates a public prospectus, namely public debt, and debt where a prospectus is not required, namely private debt. We surmise that public debt holders have access to the same set of information, as do public equity holders, thus bondholders have incentives to utilize the information contained in earnings announcements. However, firm information flows differently to the private debt markets. ${ }^{2}$ In this paper, we concentrate on the informativeness of quarterly earnings announcements to a portion of the private debt market referred to as the syndicated bank loan market.

We set out to investigate whether and when the secondary, or syndicated bank loan prices reflect information in quarterly earnings. Since these lenders may receive monthly covenant reports from borrowers reporting detailed financial and accounting information, the secondary market of syndicate loans has the opportunity to incorporate such information into the price at the time the monthly reports are released as well as at the time that quarterly earnings are announced. We further hypothesize that since lenders are exposed to downside losses, but do not share in upside gains (beyond the contractual repayment of interest and principal), it is conceivable that the loan market would be more sensitive to negative earnings information than to positive earnings

\footnotetext{
${ }^{1}$ A noted exception to this general rule is Hanjinicolaou and Kalay (1984) that examines the impact of dividend announcements on public bondholder wealth. Hotchkiss and Ronen (2002) find that both equity and publicly-held bonds respond equally efficiently to information about earnings.

${ }^{2}$ For a discussion of bank loans as privately placed debt, see Carey, Post and Sharpe (1998).
} 
information. Therefore, we expect an asymmetric price reaction in the secondary loan market.

We examine 11,034 quoted prices for syndicated loans from 196 firms for 2,127 quarterly earnings announcements over the period consisting of the last quarter of 1998 to December 2002. We utilize the Loan Pricing Corporation (LPC) marked-to-market dataset that contains weekly quotes on syndicated loans from various dealers in the secondary loan market. Using this database, we observe loan price changes prior to the announcement of each borrower's quarterly earnings releases, after controlling for relevant firm and loan characteristics that are expected to affect the impact of information about quarterly earnings announcements on loan returns. In general, we fail to find any price movements in the secondary loan market at the time of the release of the quarterly earnings announcement; that is, bank loan returns experience no significant price response at the time of the earnings announcement. However, we do find significant price movements in the secondary loan market approximately four weeks prior to earnings announcement dates, around the time of the monthly covenant reports to members of the syndicate.

We also show that the information leakage regarding upcoming quarterly earnings is asymmetric between good and bad news firms during the pre-announcement period. Bad news about earnings (i.e., declining earnings) is incorporated into bank loan prices as early as five weeks prior to the earnings announcement date, with the most significant movement occurs at four weeks prior to announcement. However, good news does not move prices as dramatically. These findings are consistent with the nature of the debt contract, which exposes the lenders to downside risk but shares no upside gains. 
Finally, we find that the information content in syndicated bank loan prices is most pronounced for borrowers with predominantly intangible assets that experience declining earnings. These intangible firms are the most informationally opaque, and thus earnings information can be expected to convey the most information about the value of the firm's assets and the prospects for loan repayment. In contrast, earnings information would be less important in valuing loans issued by firms with tangible, hard assets that can be easily valued. Thus, we find evidence that when earnings announcements convey relevant information about the borrowing firm (i.e., when the borrower has intangible assets and declining creditworthiness), the syndicated bank loan market expeditiously incorporates that information into prices.

The rest of the paper is organized as follows. Section 2 describes the secondary loan market and describes our data source. Section 3 develops our hypotheses. We discuss our regression model, variable measurement, summary statistics and the empirical results analyzing the information content of quarterly earnings in Section 4. Finally, Section 5 concludes.

\section{The Secondary Market in Syndicated Bank Loans}

Large bank loans are often underwritten by syndicates of bank and non-bank financial intermediaries, led by a lead arranger or agent bank that organizes the syndicate and negotiates the loan terms. Bank loans tend to have unique characteristics. There is a large body of academic literature (see Boot, 2000) hypothesizing that "banks may know more about a company's prospects than other investors do,"3 thereby suggesting that banks have an information advantage in providing financing for firms. This stems from

\footnotetext{
${ }^{3}$ See James (1987).
} 
their roles as delegated monitors, cultivated in the course of long-term banking relationships that include provision of a myriad of deposit, cash-management and lending services. ${ }^{4}$ Moreover, bank loans are easier to renegotiate and restructure in the event of the firm's financial distress than are publicly traded debt instruments that typically have hundreds or thousands of uncoordinated bondholders that find it hard to reach agreement, at times required to be unanimous. ${ }^{5}$ Thus, bank loans offer a certain amount of flexibility that is unavailable to issuers of bonds and other publicly traded debt securities.

Syndicated bank loans can be viewed as a hybrid between public and private debt markets (see, for example, Dennis and Mullineaux, 2000). Oldham (1998) and Miller (1998) show that syndicated bank loans trade like bonds, with fully developed securitization tools, ratings, and a broad institutional investor base. However, the syndicated bank loan market can also be viewed as a private debt market. Syndicates are formed by lead arranging banks that typically have had a lending relationship with the borrower. Moreover, the covenant structure may entitle all members of the syndicate to the receipt of monthly financial updates detailing accounting data such as EBITDA, debt levels, free cash flows and net worth. Thus, syndicate members receive considerable amounts of private information about the financial condition of the borrower. Altman, Gande and Saunders (2003) find that the bank loan market is informationally more efficient than the bond market in terms of incorporating default information into prices. Casolaro, Focarelli and Pizzolo (2003) examine loan spreads and find that the percentage

\footnotetext{
${ }^{4}$ That is, banks obtain private information about their customers by observing a history of customer information such as the flow of funds through customer checking accounts, past repayment history, customer use of commercial banking products (such as letters of credit), firm hedging activities, etc. ${ }^{5}$ In the life cycle hypothesis, firms progress from private sources of funds (including bank loans), to publicly traded debt and equity as they grow and become more well-known to the market. Moreover, Denis and Mihov (2003) find that firms with the highest credit quality issue publicly-traded bonds, whereas less creditworthy firms rely more on the private debt market.
} 
of the syndication held by the lead arranging bank is an important determinant of the information produced in the course of monitoring the activities of the borrower, suggesting that banks certify the quality of the loan by holding larger stakes. However, Allen and Gottesman (2004) find that when equity markets are relatively illiquid, equity markets are more informationally efficient than loan markets.

The Wall Street Journal (October 29, 2001) referred to the syndicated loan market as a "multi-trillion dollar debt bazaar that has become the nation's largest capital market during the last decade."6 Many factors contributed to the rapid growth in the syndicated loan market during the 1990s. The advent of Rule 144a in 1990 (for a discussion of this rule, see Press and Weintrop, 1999) permitted the resale of privately-held securities. Moreover, the 1991-1992 credit crunch, exacerbated by the adoption of more stringent, risk-based international bank capital requirements, contributed to the banking system's willingness to sell their loans into the secondary market, rather than hold them until maturity. Liquidity in the market was bolstered by the founding of the Loan Syndication and Trading Association (LSTA) and the adoption of standardized T+10 settlement procedures for par and near par loans. Thomas and Wang (2004) demonstrate that the leveraged loan market has been integrated into the high yield debt market since 1994, suggesting that the same factors that impact junk bond prices also impact leveraged loan prices. $^{7}$

\subsection{The Loan Pricing Corporation Database and Sample Selection}

Our major database is obtained from the Loan Pricing Corporation (LPC) and consists of two components: the marked-to-market database and Dealscan. The marked-

\footnotetext{
${ }^{6}$ Zuckerman and Sapsford, (2001).

${ }^{7}$ Leveraged loans are non-investment grade loans made to highly leveraged borrowers. They are priced at spreads that exceed 200 basis points over LIBOR.
} 
to-market database consists of weekly loan bid and ask quotations for individual loan facilities. ${ }^{8} \quad$ Loan deals are typically broken into individual facilities. Each facility represents a different tranche of the total loan. The facilities may differ in terms of their covenants, structure (revolving versus term loans), maturity, spreads, etc. For each individual facility, LPC provides an average of all available bids and an average of all available asks, and the mean of the average bid and the average ask (denoted mean of mean quote), as well as the number of quotes that comprise the composite average. Transaction prices are not available in the syndicated bank loan market. However, internal LPC studies suggest that transactions prices for par loans (priced above 90) are close to the mean of the mean bid and mean ask quotes (hereinafter, denoted the LPC mean of the mean). Thus, we use the LPC mean of the mean to determine the value of a particular loan facility, denoted $P_{i t}$ for any given borrower $i$ in any given week $t$.

We coordinate the marked-to-market database with loan descriptive data provided on LPC's Dealscan database of primary market data. ${ }^{9}$ The Dealscan database contains detailed data about the borrower, the lending syndicate and the terms of the loan itself (including financial and general covenants, optionality in pricing, amorization schedules, lending purpose, etc.). After combining the two databases, we obtain a sample consisting of 1,639 unique loan facilities with 249 variables describing the terms of the loan facility, the borrower, the lenders, the composition of the syndicate and the pricing of the loan weekly over the June 1998 through May 2003 period.

\footnotetext{
${ }^{8} \mathrm{LPC}$ is a data warehouser, collecting daily price quotes from more than 30 dealers in the syndicated bank loan market and making them available for use in the marked-to-market database. We acquired a limited version of this database that includes weekly price quotations over the period of June 1998 to June 2003. Moreover, our observations are limited to those loan facilities with at least two quoting dealers. Our full database contains 184,710 facility prices.

${ }^{9}$ See Dichev and Skinner (2002) for a discussion of the database.
} 
We combine the LPC databases with quarterly Compustat data in order to obtain financial information about earnings, size and leverage. Imposing the requirement of Compustat data availability further limited our sample to 878 loan facilities. In order for a firm to remain in the sample, we choose those firms in the combined LPC database with quarterly earnings announcements from Compustat, subject to the following criteria:

1. Each facility must have at least 25 time-series observations of quoted loan prices.

2. Only one facility per firm was selected to avoid interdependence among realized returns. The facility that was chosen has the longest time-series observations of quoted prices, i.e., it is the most frequently "traded" facility to reduce the infrequent "trading" problem associated with private debt.

3. There had to be at least one year of quarterly earnings announcement dates available from Compustat during the time period of the loan trades.

4. For each of the earnings announcements there had to be at least two quoted prices within our -6 week to +6 week return window, with 0 being the week of the announcement.

5. The weekly return on a leveraged loan index (the S\&P/LSTA loan index) is available.

The selection process yields 11,163 firm-quarter observations. To control for the effects of extreme values, we remove those observations that are identified as outliers in the regressions. ${ }^{10}$ We report our tests in the paper based on our final sample of 11,034 firm-quarter observations.

\footnotetext{
${ }^{10}$ To control for outliers, we remove from all of our tests any observation that has a studentized residual greater than four standard deviations from zero in any pooled regression of loan returns on change in quarterly earnings. There were only 129 observations that were removed from the analysis as outliers.
} 


\section{Hypotheses Development}

\subsection{The Timing of the Price Reaction to Earnings Announcements}

There is a voluminous literature in both accounting and finance dating back to Ball and Brown (1968) and Beaver (1968) that deals with the market's response to earnings announcements. The persistence of this finding is documented in Landsman and Maydew (2002). They find no evidence of a decline in the information content of earnings announcements over the past three decades. Indeed, they find an increase in the informativeness of earnings announcements over time, as measured by abnormal stock price volatility and abnormal trading volume.

Since both debt and equity represent claims on the firm's assets, any change in investors' expectations of future cash flows will influence the pricing of debt, as well as equity, securities. Thus one could hypothesize that a similar earnings announcement effect would be reflected in debt prices as is found in equity prices. In a paper that tests the information content in public debt prices at the time of annual earnings announcements, Davis, Boatsman and Baskin (1978) find that there is an association between the price of public debt and the announcement of annual earnings. ${ }^{11}$ Our hypotheses are designed to test whether the results of the extant literature demonstrating earnings announcement effects in equity and public debt markets apply to syndicated bank loan markets.

\footnotetext{
${ }^{11}$ In a related paper, Hanjinicolaou and Kalay (1984) examine the information content in public debt and equity prices at the time of dividend changes. The main thrust of their paper is to distinguish the information content hypothesis from a wealth transfer hypothesis. This suggests that the change in dividend policy effectively transfers wealth from the debt to the equity holders when dividends are increased. The authors find no support for the wealth transfer hypothesis, but do find support for the information content hypothesis.
} 


\section{$H_{1}$ : Information about quarterly corporate earnings is reflected in bank loan prices}

on announcement dates.

In testing this hypothesis, we examine whether the results that are prevalent in the equity market literature showing significant announcement date reactions to earnings, hold for the syndicated bank loan market. A finding in support of $H_{l}$ would suggest that bank loan returns and equity returns have similar reactions to earnings announcements. However, there are several reasons why bank loan prices may react differently to earnings announcements than do equity prices, thereby leading to a rejection of $H_{1}$.

At the heart of most of the studies of equity market reaction to earnings announcements is the assumption that the release of important data about the firm, such as earnings, is made available to all investors at the same time. ${ }^{12}$ However, investors in different markets may be the recipients of different types of information flows. The different flows could be a result of the efforts (costs) that particular investors are willing to incur in order to obtain data. In particular, private debt markets, such as the syndicated bank loan market, require the periodic transfer of data on the borrowing firm's economic prospects such as future earnings and cash flows. If this information has is useful in evaluating the firm's debt claims, we would expect to see a response in bank loan prices to the release of this information would precede the earnings announcement date. Because private debt markets may have access to different sources of information at different points in time, we may, therefore, observe different responses to information about corporate earnings in the syndicated bank loan market as compared to the public equity and debt markets. For example, Altman, Gande and Saunders (2003) compare the

\footnotetext{
${ }^{12}$ Jorgensen and Wingender (2004) find that quarterly earnings announcements are disseminated broadly to public markets via telephone and the Internet, particularly in the wake of the passage of Regulation FD in October 2000.
} 
information content of trading in the syndicated bank loan market to the publicly-held bond market and find that the syndicated bank loan market is more informationally efficient than the market for publicly traded bonds.

A further difference in any reaction to information about the future cash flows of the firm relates to potential differences in the way that holders of debt versus equity respond to the same information. That is, debt and equity prices may respond differently to the same information. If, for example, the information reflects an increase in a firm's asset values, then both its debt and equity prices will tend to increase. However, if the information reflects an increase in the volatility of asset values, all else being equal, then debt prices will decline whereas equity prices will increase. The negative correlation of debt and equity prices to asset volatility stems from the short put option nature of debt (that is, debt holders issue a put option on the firm's assets to equity holders) as compared to the call option qualities of equity. Thus, ceteris paribus, debt values decline (increase) when volatility increases (decreases), whereas equity values increase (decrease) when volatility increases (decreases). Another reason why we might expect a differential informational impact of earnings announcements on debt prices as compared to equity prices is the market's differing informational efficiency. Although Blume, Keim and Patel (1991) and Cornell and Green (1991) find a strong contemporaneous relationship between bond returns and stock returns, Kwan (1996) suggests that stock markets are more informationally efficient than are bond markets. 


\subsection{Asymmetric Responses to Information About Earnings}

Prior literature has posited that there may be an asymmetric price response between news that reveals a firm's deteriorating future economic prospects as compared to the price reaction to news that reveals a firm's rosy future economic prospects (Hayn, 1995). However, extant equity-based research provides mixed findings on this issue. For example, by regressing raw returns on firm earnings, Hayn (1995) finds that the earningsreturns relation is much stronger for profitable firm-years than when all firm-years are included. However, Chambers (1996) reports that when sample firms are size-matched, firms with declining earnings tend to have a higher $\mathrm{R}^{2}$ than do firms with increasing earnings. In replicating the tests of Hayn (1995) using inter-announcement period marketadjusted returns, Basu (1997) finds that the earnings-returns relation is stronger for the full sample than for increasing earnings firms only. He interprets his results to be consistent with the conservatism in accounting as bad news regarding future cash flows is recognized in earnings in a more timely manner than is good news. Similar findings can be found in examining the stock market reactions to bond rating changes. For example, Holthausan and Leftwich (1986) find significant abnormal stock returns associated with bond downgradings, but not with upgradings. Moreover, Handjinicolaou and Kalay (1984) find that gains associated with positive dividend announcements are captured by the stockholders (and not the bondholders), while the losses resulting from negative dividend announcements are shared with the bondholders. Therefore, we test the following null hypothesis:

$\mathrm{H}_{2}$ : The information content of earnings in the syndicated loan market is symmetric, such that firms that have releases of data indicating positive future prospects 
realize the same market reaction as do firms that release data indicating negative future prospects.

From a creditor's point of view, timely information about "bad news" is more important than information about "good news," since the value of creditors' claims on a firm's assets is more sensitive to a decline than an increase in the firm's future economic prospects (Smith, 1979). Due to the nature of the debt contract, lenders are exposed to downside losses, but do not share in upside gains (beyond the contractual repayment of interest and principal). Therefore, we expect the information content of earnings in the secondary syndicated loan market to be asymmetric between firms that release earnings indicating negative future economic prospects (denoted, bad news) and those announcing increasing earnings (denoted, good news). More specifically, we expect syndicated loan returns to be more sensitive to bad news than to good news, thereby rejecting $\mathrm{H}_{2}$.

\subsection{The Impact of Earnings Information For R\&D Intensive Firms}

Our last hypothesis relates to the source of firm financing. Firms obtain financing from many sources - issuance of equity, preferred stock, (straight and convertible) bonds and other debt instruments, including loans from banks. Informationally opaque firms are likely to rely on bank loans for a portion of their sources of financing in order to benefit from the monitoring activities of the bank lender, as well as to obtain potential signaling advantages associated with loan approvals. ${ }^{13}$ Diamond (1991) shows that borrowers tend to move from private resources to the public debt market when the quality of the firm's information improves. Pennachi (1988) demonstrates that when the benefits of sellers' monitoring of the loan become negligible, a loan can be sold in its entirety.

${ }^{13}$ See James (1987) and Dahiya, Puri and Saunders (2004). 
This is true for firms that are less informationally opaque, and therefore, can be evaluated using public information by arms-length investors.

In contrast, firms with large amounts of intangible assets are difficult for public capital markets to evaluate and monitor. With their relative paucity of hard assets and the proliferation of growth opportunities and other intangible assets on their balance sheets, intangible firms may be rationed out of public capital markets because of the potential for extreme moral hazard risk shifting resulting from information asymmetries. Often private debt, such as the bank loans and venture capital, are the only sources of capital available to these firms. Houston and James (1996) show that private debt represents $83 \%$ of outstanding corporate debt in their sample, with the majority of firms in their sample relying exclusively on private debt.

It is for intangible firms, however, that information is simultaneously most critical and least available. Thus, we hypothesize that the information content of accounting earnings is larger for firms in which intangibles comprise a large proportion of their assets. This is often reflected in R\&D intensive industries. Following Barron et al. (2002), we define R\&D intensive firms to be high-technology manufacturing firms. The central characteristics of these R\&D intensive firms is that they develop most of their intangibles (e.g., R\&D) internally, and yet according to the current accounting standards, these intangibles have to be fully expensed, rather than capitalized on the balance sheet. Compared with capitalization, full expensing of these R\&D expenditures implies a higher uncertainty regarding whether and when the future economic benefits from these expenditures can be realized, which gives rise to the "opaqueness" of their financial information. This leads us to our last hypothesis. 
$H_{3}$ : The information content of earnings in the syndicated loan market is the same for $R \& D$ intensive firms as for other firms.

The highly uncertain nature of intangibles, combined with the accounting treatment for these internally developed intangibles, makes it more difficult to observe and interpret the financial information for R\&D intensive firms. Accordingly, the demand for timely information about these firms is larger, and so is the information content of accounting earnings. Thus we expect to reject $H_{3}$.

\section{The Empirical Model and Results}

\subsection{Variable Definitions}

\subsubsection{Loan Returns and Index Loan Returns}

To test the hypotheses described in section 3 , we define the following variables. The dependent variable in our event study, $R_{i t}$, is the weekly return on each individual syndicated bank loan facility. We use weekly (mean of the mean) quotations obtained from LPC to obtain syndicated bank loan prices and calculate the raw return by taking the $\log$ difference of two consecutive weekly quotes. More specifically, our dependent variable $R_{, i t}$ is measured by the following:

$$
R_{i t}=\operatorname{Ln}\left(P_{i t} / P_{i t-1}\right)
$$

where

$R_{i t}=$ the rate of return of syndicated loan facility $i$ between the closing quote at week $t-1$ to the closing quote at week $t$, $P_{i t}=$ quoted LPC mean of the mean price of loan facility $i$ at week $t$. 
The calculation of holding period returns, $R_{i t}$, is complicated by several factors.

First, the weekly quotes may not be consecutive. If the weekly quotes are not consecutive, we denote the weeks of missing quotes as missing observations, i.e., we don't replace missing consecutive returns with multi-week returns. ${ }^{14}$ Second, the dates for which these quotes are available change across loan facilities, and even over time for the same loan facility. To correctly locate each quote in terms of its distance to each earnings announcement date, we designed the following methodology:

1. Let $W_{i s}$ be the first day of the week during which quarterly earnings for firm $i$ are announced,

2. Let $N$ be the distance in terms of weeks from the observed date of quote in week $t$ of loan facility $i$ to $W_{i s}$,

3. Let $K$ be the integer of $N$, and restrict $K$ to be $[-6,+6]$, since we expect each quarterly earnings announcement to be approximately 12 weeks apart, ${ }^{15}$

4. For each quarterly earnings announcement of each firm, we index every $P_{i t(K)}$ by $K$, where $K=[-6,+6]$,

5. If the earnings announcement date comes before or at the same time as the date of the quote in a particular week $t$, let $R_{i, t(K)}=\operatorname{Ln}\left(P_{i, t(K)} / P_{i, t(K-1)}\right)$, with $K \sim[-5,6]$,

6. If the earnings announcement date comes after the date of the quote in a particular week $t$, let $R_{i, t(K)}=\operatorname{Ln}\left(P_{i, t(K+1)} / P_{i, t(K)}\right)$, with $K \sim[-5,6]$.

\footnotetext{
${ }^{14}$ We differ from Hanjinicolaou and Kalay (1984) in dealing with non-consecutive trades for the following reasons. First, Hanjinicolaou and Kalay (1984) use daily trading data on bond, whereas we only have weekly data. Second, our main interest is about the timing of loan price response to earnings information during the pre-announcement period, while Hanjinicolaou and Kalay (1984) test how the bond market react to dividend change announcements. Calculating multi-day returns will not affect the inferences regarding how the market reacts. However, calculating multi-week returns will affect the inference regarding when the market reacts.

${ }^{15}$ If two adjacent earnings announcement dates are less than 12 weeks apart, then we have an overlap problem in terms of indexing our weekly quotes. For example, one firm in our sample announced the $4^{\text {th }}$ quarter earnings of the prior year on February 14, and announced the first quarter earnings of the current year on April 24, so that the +6 week event corresponding to the February earnings announcement overlaps the -6 week event for the next earnings announcement. In that case, we consider the +6 week observation to be missing, since our main interest lies in examining the loan returns prior to earnings announcements.
} 
To estimate the market return during a particular week $t$, denoted $M R_{t}$, we obtain weekly quotes on the S\&P/LSTA syndicated bank loan index. LSTA, in conjunction with Standard \& Poor's, maintains a weekly index of senior bank loan prices. The S\&P/LSTA syndicated bank loan index currently includes 470 loan facilities totaling $\$ 104$ billion in value outstanding, covering around $70 \%$ of the institutional loan market. Starting in January 1999, the S\&P/LSTA index provides weekly quotes on the leveraged loan market. To align loan index return with each individual loan return, we repeat the indexing procedure described above on the S\&P/LSTA weekly index quotes, for each quarterly earnings announcement and for each firm.

\subsubsection{Testing Variables}

We examine the impact of the quarterly earnings announcement on the dependent variable, the weekly loan return $R_{i t}$. Following Beaver et al. (1997), the quarterly earnings variable, denoted $C E_{i q y}$, is the change in earnings for quarter $q$ from the current year $y$ to the year $y$-1, normalized by the level of earnings for quarter $q$ in the year $y-1$. We test the timing of the earnings announcement using an indicator variable, $K_{i t}$, that is set equal to one if the observed loan return for facility $i$ in week $t$ is $K$ weeks prior to the earnings announcement week; zero otherwise. We observe loan price behaviors from five weeks prior to the earnings announcement (i.e., week $K=-5$ ) to the week of the earnings announcement (i.e., week $K=0$ ). ${ }^{16}$ Our primary interest is to find out how loan prices respond to the forthcoming earnings information during the five weeks of preannouncement period, i.e., whether there is information leakage during the preannouncement period in the private debt market.

\footnotetext{
${ }^{16}$ We start from week -5 because we don't have enough observations for week -6 .
} 
Since we expect an asymmetric price reaction to earnings information, we split the sample into observations with an increase in the upcoming earnings announcement (denoted, good news) and observations with a decrease in the upcoming earnings announcement (bad news). Specifically, we separate good news firms from bad news observations for each firm $i$ using annual unscaled changes in earnings per share, as calculated from quarter $q$ in year $y-1$ to the same quarter in year $y$; that is, $\hat{C E}_{i q y}=E_{i q y}-$ $E_{i q y-1 .}$. If the change in earnings is less than zero, then that firm-quarter observation is classified as bad news; otherwise, it is put into the good news sample. ${ }^{17}$

We are also interested in whether differences exist between intangible-intensive firms versus non-intangible-intensive firms in terms of the informativeness of syndicated loan prices. For firms with high amounts of intangibles, the information asymmetry is largest due to the nature and extent of uncertainty associated with intangibles (Lev, 2001). Prior studies (Barth et al., 2001, Barron et al., 2001) have found high information content in analyst forecasts for high intangible-intensive firms. Therefore, we expect intangible firms to have a greater price impact before an earnings announcement.

To test whether the information content of corporate earnings announcements is related to the tangibility of a firm's assets, (hypothesis $H_{3}$ ), we utilize an indicator variable differentiating intangible-intensive firms versus non-intangible-intensive firms. Following Amir, Lev and Sougiannis (2003), we define intangible intensive firms using the following three-digit SIC codes: 283 (Drugs); 284 (Chemicals); 357 (Computer and Office Equipment); 366 (Communications Equipment); 367 (Electronics); 371 (Motor

\footnotetext{
${ }^{17}$ We use this definition of bad/good news (as in Foster (1977) and Kothari (2001)) because more complicated time-series models have not improved the results in other studies testing the relationship between short-window returns and quarterly earnings announcements.
} 
Vehicles); 382 (Measurement and Control Devices); 384 (Medical Instruments); and 737

(Software). ${ }^{18}$ We then construct a dummy variable, denoted INTANGIBLE $E_{i}$, set equal to one for these three-digit SIC codes, and zero otherwise. We use the INTANGIBLE $E_{i}$ variable to break our full sample into four subsamples: good news (increasing earnings) intangible $\left(I N T A N G I B L E_{i}=1\right)$ firms, good news tangible $\left(I N T A N G I B L E_{i}=0\right)$ firms, bad news (decreasing earnings) intangible firms and bad news tangible firms.

\subsubsection{Other Control Variables}

It is well known that firm size is negatively associated with stock returns (Schwert, 1983; Easton and Zmijewski, 1989). Since firm size can be related to many economic factors of a firm, such as systematic risk, the association between firm size and syndicated loan returns is unpredictable. As a control variable, we use the standard size variable $S I Z E_{i q}$ defined to be the $\log$ of the market capitalization of firm $i$ at the beginning of quarter $q$ (where $q$ encompasses weeks $K \sim[-5,6]$ ), as obtained from Compustat quarterly tapes.

Loan prices are extremely sensitive to default risk. As a proxy for the loan's credit risk, we use Moody's senior debt ratings information on each loan facility, as provided in the LPC Dealscan database. ${ }^{19}$ We coded RATING $_{i}$ into 1 through 7 to represent the ratings of Aaa, Aa, A, Baa, Ba, B and lower than B. Higher default risk (a higher value of $\left.R A T I N G_{i}\right)$ is related to lower loan returns, therefore, we expect a negative relation between $\operatorname{RATING}_{i}$ and the dependent variable.

\footnotetext{
${ }^{18}$ For robustness checks, we also defined intangible firms to be those firms with a Tobin's q exceeding one and obtained similar results to those presented in the paper.

${ }^{19}$ These credit ratings are assigned as of the loan origination and may change over the life of the loan. As a robustness check, we therefore defined the probability of default for each loan facility $i$ at each week $t$ using a structural model similar to that of Merton (1974). For a description of options-theoretic credit risk measurement models, see Saunders and Allen (2002), chapter 4.
} 
The last set of variables controls for loan specific features. The interest rate on the loan is measured as the natural log of the basis point spread over LIBOR, inclusive of all fees, called the all-in-spread, denoted $L S P R E A D_{i t}$. In general, this spread is fixed over the life of the loan.$^{20}$ Ceteris paribus, the higher the spread, the riskier the loan. High credit risk loans generally experience lower returns. John, Lynch and Puri (2002) find a negative relationship between yields on corporate bonds and risk (as measured by credit ratings). Therefore, a negative relationship between returns and $L S P R E A D_{i t}$ is expected in the context of syndicated bank loans. To measure the liquidity of the syndicated bank loan market for facility $i$ in week $t$, we define NOQUOTES $S_{i t}$ to be the log of the number of weekly quotes. Since loans trade at an illiquidity discount, the more liquid the loan (the higher the NOQUOTES ${ }_{i t}$ ), the lower the required rate of return.

An indicator variable DISTRESS ${ }_{i t}$ specifies whether the loan is distressed or not. It is set equal to 1 (zero otherwise) if the mean of the mean price of facility $i$ in week $t$ for a particular quarterly earnings announcement event is less than 80 . During the time period of our study (1998-2002), many of the distressed loans in our sample are "fallen angels," i.e., par loans that declined in value as the borrowing firm experienced deterioration in its creditworthiness. This price decline would produce a negative relationship between loan returns and the DISTRESS $S_{i t}$ control variable. We also define a dummy variable that takes on the value of one if the loan has financial covenants that might require special reporting of financial and accounting data, denoted $\operatorname{COVENANT} T_{i}$. The existence of financial covenants obligates the borrower to reveal detailed accounting data to the loan syndicate on a periodic basis (usually monthly). Because this condition would reduce the market's

\footnotetext{
${ }^{20}$ The exception to this is for loans with a performance pricing grid, that specifies changes in the spread in response to changes in the borrowing firm's financial condition, as measured by credit rating or accounting ratio.
} 
uncertainty about loan value, therefore, ceteris paribus, we anticipate a negative (positive) relationship between loan returns and the COVENANT $T_{i t}$ dummy variable for bad (good) news firms. ${ }^{21}$ Another indicator variable is set equal to one (zero otherwise) if the loan is secured by collateral, denoted $S E C U R E D_{i}$. Since secured loans tend to be riskier, thereby accounting for the collateral requirement, (see, for example, Berger and Udell, 1990), we anticipate a positive relationship between loan returns and the $S E C U R E D_{i t}$ dummy variable, all else equal. We also include the log of years to maturity of the loan $\left(M A T U_{i}\right)$ to control for the degree of interest rate exposure. Longer maturity results to higher interest rate exposure. Hence, it is expected to be positively related to loan returns. Finally, we use log of the size of the loan facility $\left(L_{O A N S I Z E}\right)$ to measure each loan's marketability. The larger the size of the loan, the more frequently the loan is expected to be traded, which is expected to be negatively related to the return of the loan.

\subsubsection{The Empirical Model}

We estimate the following model to examine the information content of quarterly earnings announcements in syndicated bank loan prices:

$$
\begin{aligned}
& R_{i t}=\alpha+\beta_{1} M R_{t}+\beta_{2} C_{i q}+\beta_{3} \text { SIZE }_{i q}+\beta_{4} \text { RATING }_{i}+\beta_{5} L S P R E A D_{i t} \\
& +\beta_{6} \text { NOQUOTE }_{i t}+\beta_{7} \text { DISTRESS }_{i t}+\beta_{8} \text { COVENANT }_{i}+\beta_{9} \text { SECURED }_{i} \\
& +\beta_{10} \text {MATU }_{i}+\beta_{11} \text { LOANSIZE }_{i}+\beta_{12} K_{i t}+\varepsilon_{i t}
\end{aligned}
$$

Equation (2) is re-estimated six times for $K=-5,-4,-3,-2,-1,0$ representing the week of the observed loan returns prior to a quarterly earnings announcement.

\subsection{Descriptive Statistics}

\footnotetext{
${ }^{21}$ Bradley and Roberts (2004) use the LPC Dealscan database and find an inverse relationship between loan yields and the presence of covenants.
} 
Table 1 presents descriptive statistics of the 11,034 loan return observations. Panel A reports the summary statistics of the variables in the overall sample. As can be seen from Panel A of Table 1, the average weekly return on the loan facilities in our sample as a whole is slightly negative over the sample period, and the average percentage change in quarterly earnings over the same period is -0.5433 . Given that our sample period covers the Russian debt default, the bursting of the high tech bubble and the resulting recession in the US, syndicated loan prices generally declined over the 1998-2002 period. The average firm size in our sample is around 3.2 billion dollars, with the smallest firm's market capitalization of 0.7 million dollars and the largest of 103 billion dollars, which indicates that our sample firms are widely distributed in their sizes. In terms of industry classification, about $30 \%$ of the borrowing firms in our sample are in intangible-intensive industries. The average Tobin's q ratio for all firms in our sample is 0.9674 . In terms of the loan facilities in our sample, $17.6 \%$ are distressed loans, $86.2 \%$ have financial covenants, and $88.3 \%$ of them are secured. The average loan spread is about 287 basis points over LIBOR, the average number of quotes is around 9, the mean maturity of the loans is slightly over 6 years, and the average loan size is around $\$ 560$ million.

The most common financial covenant requires monthly reporting of EBITDA in order to calculate the borrower's debt to EBITDA ratio. In our full LPC database, $94.69 \%$ (out of a total of 1,148 loan facilities) of the loans specified a covenant limiting the maximum allowable debt to EBITDA ratio, with a median initial maximum allowable debt to EBITDA ratio of 5.50. Another common financial covenant (specified in $22.21 \%$ of the loan facilities in the full sample) is a minimum net worth limitation (median value of $\$ 237.3$ million). 
Since we expect an asymmetric price reaction to earnings information, we split the sample into observations with an increase in the upcoming earnings announcement (denoted, good news) and observations with a decrease in the upcoming earnings announcement (bad news). As can be seen from Table 1, the sample is rather evenly split: 6,003 observations in the good news subsample and 5,031 observations in the bad news subsample. We report the summary statistics of the loan observations in the bad news and good news subsamples in Panels B and C of Table 1, respectively. We further test the mean and variance differences between the bad and good news subsample in Panel D of Table 1. As seen from Table 1, Panel D, the loan observations in the bad news group are significantly different (at the $5 \%$ level or better) from the good news group observations. On average, loans in the bad news group have lower weekly returns, lower credit ratings, and higher spreads over LIBOR. Moreover, bad (good) news observations tend to be clustered during times when the loan market declined (increased), as shown by the positive t-statistic for the market return $\left(M R_{t}\right)$ mean difference. Bad news is observed, on average, for companies that are more likely to be in intangible-intensive industries. Loan facilities in the bad news group tend to be larger, have greater liquidity (in terms of the number of quotations) and shorter maturity. They are less likely to be secured, to have financial covenants, but more likely to be distressed.

\subsection{Empirical Results}

To present an overview of our empirical results, in Figure 1 we plot weekly returns on syndicated bank loans in a return window of $[-6,+6]$ weeks around quarterly earnings announcements. A cursory review reveals that there is little or no significant 
loan price reactions to the corporate earnings announcement itself, but bad news (declines in earnings) are reflected in debt prices about a month before the earnings announcement date. There is no similar debt price reaction to good news (increases in earnings). ${ }^{22}$

Evidence in Figure 1 seems suggest that there is significant information leakage regarding the upcoming declines in earnings during the pre-announcement period in the secondary syndicated loan market. These illustrative results motivate us to proceed to the more rigorous empirical tests of our hypotheses.

We begin our formal tests with an estimate of equation (2) using panel data that is pooled both cross-sectionally and intertemporally. We include year indicator variables to allow the intercepts to vary by year from 1998 to $2003 .^{23}$ We estimate equation (2) for the overall sample of firms, as well as for various subsamples separately, in order to test our three hypotheses.

Table 2 presents the estimation of equation (2) for the entire sample for each of weeks $K=-5$ to the week of the earnings announcement $(K=0)$ consecutively. Results in Table 2 indicate that the only week coefficient that is significant at the $5 \%$ level is -0.0006 for week $K=-4$, suggesting that there is a negative announcement effect approximately one month prior to the earnings release dates. Interestingly, we find that the coefficient on the $K_{\mathrm{it}}$ dummy variable when week $K$ equals 0 is insignificantly different from zero. This finding is quite different from the stylized fact in the equity market that earnings announcements are associated with significant stock market movements. We thus reject the null hypothesis $H_{I}$ that the information content of

\footnotetext{
${ }^{22}$ We conduct a similar test on raw equity returns at the time of the earnings announcement. As one would expect, there is a statistically significant increase in security prices at the time of the release of the earnings announcement.

${ }^{23}$ Because the coefficients on the year variables were generally insignificant, they are not reported in Tables 2-4.
} 
earnings announcements is reflected in bank loan prices on the announcement date. Due to the unique information flows in the syndicated bank loan market, the information about corporate earnings is reflected in bank loan prices approximately four weeks prior to the announcement. That is, private lenders know about earnings information earlier than other public security holders.

Consistent with our expectations, the coefficient on the loan rating variable is negatively significant in all of our regressions reported in Table 2, which indicates that the higher the value of the $R A T I N G_{i}$ variable, the lower the loan's credit rating, the higher the default risk, and the lower the weekly loan returns. Firm size and loan facility size are also significant negative, indicating that the larger the firm and the larger the size of the loan, the lower the loan returns. The log of the All-In-Spread variable, and the number of weekly quotes variables are significantly negative, consistent with our expectations that the more liquid the loan, the lower the returns.

However, the results in Table 2 are obtained for the aggregate sample, and therefore, cannot be used to test $H_{2}$, which hypothesizes an asymmetric response in bank loan prices to good versus bad news. In Table 3, we re-estimate equation (2) for the bad news and good news subsamples separately. ${ }^{24}$ The insignificant coefficient on $K_{i t}$ for week equals zero in both Panel A (bad news subsample) and Panel B (good news subsample) further supporting our conclusion that earnings announcements are not reflected in loan prices during the week of the announcement event (i.e., we reject $H_{l}$ ). Moreover, none of the week indicator variables' coefficients are significant for the good news subsample, suggesting that there is no significant impact on loan returns resulting

\footnotetext{
${ }^{24}$ We also used a dummy variable for Good News/Bad News in equation (2) as both a control variable and as an interactive variable (i.e., cross-product with the week dummies, the change in earnings variable, etc.), and found similar results to those presented in Table 3 for the disaggregated subsamples.
} 
from increases in earnings. In contrast, however, the adjusted $\mathrm{R}^{2} \mathrm{~s}$ in the bad news group regressions are $1.22 \%$ and larger, compared with those of less than $0.4 \%$ in the good news subsample regressions. More importantly, the coefficients on week $K=-5$ and week $K=-4$ are statistically significant (at the $5 \%$ level or better) for the bad news subsample, suggesting that declines in earnings are reflected in loan returns approximately one month ( 4 or 5 weeks) before the actual earnings announcement. The signs of both of these coefficients are negative, suggesting that loan returns decline one month prior to the announcement of earnings declines. This time period corresponds to the time frame during which bank loan syndicate members generally receive covenant reports that may include detailed financial information on earnings. Thus, when deteriorating financial information of the borrowers becomes available to private lenders, the secondary loan market expeditiously reflected that information into loan prices. However, improving financial information about borrowers is not reflected in syndicated loan prices, suggesting that loan contracts generally expose lenders to downside risk, but not the upside gains. Therefore, our finding of an asymmetric reaction in loan prices to good versus bad news is consistent with the nature of the debt contract, which suggests a rejection of the null hypothesis $H_{2}$.

Similar to the results in Table 2, we find that $\log$ of firm size, loan rating as well as the number of weekly quotes of a loan are significantly negative in our bad news subsample. The financial covenant indicator variable is also negative significant, indicating that the existence of financial covenants obligates borrowers to reveal "bad" accounting data to the loan syndicate, which lowers the return of their loans. For good news firms, we find this covenant variable to be positive, consistent with the view that 
periodic "good" accounting information of the borrower reduces the uncertainty about its loan's market value, which slightly increases the loan returns.

Finally, we test hypothesis $H_{3}$ to see if there is an asymmetric impact on bank loan prices that depends on the level of tangibility of the borrowing firm's assets. In Table 4, we estimate equation (2) separately for each of four subsamples: the bad news/intangible firms (characterized by earnings declines and borrowing firms classified in intangible industries - regression results reported in Table 4, Panel A); the bad news/tangible firms (Panel B); good news/intangible firms (increasing earnings and borrowing firms classified in intangible industries - Panel C) and the good news/tangible firms (Panel D). As can be seen from Table 4, the adjusted $\mathrm{R}^{2} \mathrm{~s}$ for regressions on firms in the intangible-intensive industries are always larger than the adjusted $\mathrm{R}^{2} \mathrm{~s}$ for regressions on firms in less intangible-intensive industries. For bad news group, the adjusted $\mathrm{R}^{2} \mathrm{~s}$ for regressions on intangible firms are $4.75 \%$ and larger, compared with those of less than $0.9 \%$ in the tangible firms regressions. Similarly for the good news subsample, the adjusted $\mathrm{R}^{2} \mathrm{~s}$ for regressions on intangible firms are $1.31 \%$ and larger, compared with those of $0.03 \%$ in the tangible firms regressions. These findings indicate that accounting information is generally more helpful in explaining loan returns when the borrowers have more intangible assets on their balance sheets.

As can be seen from Table 4, none of the week dummy variables (for $K=-5$ to 0 ) are statistically significant for the good news groups (Panels C and D). However, the -0.001 coefficient on the variable indicating week $K=-4$ prior to the earnings announcement date is significant at the 5\% level for the bad news/tangible firms (Panel B). Most striking, however, is that the week $K=-4$ and $K=-3$ coefficients are also 
significant at the $1 \%$ level for the bad news/intangibles firms (Panel A). Moreover, the absolute value size of the negative coefficients are larger $(-0.0028$ and -0.0021$)$ than for the bad news/tangible firms (-0.001), suggesting a greater decline in loan returns for intangible firms experiencing decreases in earnings as compared to any other group. The coefficient on the size of the earnings decline, $C E_{i t}$, is statistically significant at the $10 \%$ level or better for the bad news/intangible firm group only, suggesting a further decline in loan returns for these firms. Thus, we find evidence that supports the existence of an asymmetric information effect of quarterly earnings announcements on bank loan returns for firms with intangible assets experiencing earnings declines. That is, earnings and other cash flow information are most important for informationally opaque firms with intangible assets that have financial difficulties. Our findings therefore reject the null hypothesis $H_{3}$ in favor of this asymmetric impact effect.

\section{Conclusion}

In this paper, we utilize quotations for syndicated bank loans in order to examine the information content of quarterly earnings announcements to private debt holders in the syndicated bank loan market. We find that this market reflects information about accounting earnings into loan prices approximately one month prior to its reflection in equity prices equity market. Moreover, we find evidence that bank loan prices are impacted by declines in earnings rather than increases in earnings, consistent with the nature of debt as exposed to downside loss, but with limited upside gain potential. Finally, earnings information is most relevant and has the largest impact on bank loan prices if the borrowing firm's assets are intangible and therefore difficult to evaluate and 
monitor. Thus, earnings information is used by investors in the bank loan market to price syndicated loans when other sources of information are either unavailable or unreliable. 


\section{References}

Affleck-Graves, J., C.M. Callahan and N. Chipalkatti, "Earnings Predictability, Information Asymmetry and Market Liquidity," Journal of Accounting Research 40 (2002): 561-583.

Allen, A. and A. Gottesman, "The Informational Efficiency of the Equity Market as Compared to the Syndicated Bank Loan Market," August 2004, Baruch College Working Paper.

Altman, E.I., A. Gande and A. Saunders, "Informational Efficiency of Loans versus Bonds: Evidence from Secondary Market Prices," April 2003, NYU Working Paper.

Amir , A., B. Lev, and T. Sougiannis, “Do financial analysts get intangibles?” 2003 European Accounting Review. Forthcoming.

Ball, R. and P. Brown, “An Empirical Evaluation of Accounting Income Numbers," Journal of Accounting Research 6 (1968), 159-178.

Barron, O., D. Byard, C. Kyle and E. Riedl, "High Technology Intangibles and Analysts' Forecasts," Journal of Accounting Research 40 (2001) Supplement: 289-312.

Barth, M.E., J.A. Elliott, M.W. Finn, "Market Rewards Associated with Patterns of Increased Earnings," Journal of Accounting Research 37(1999): 387-413.

, R. Kasznik, and M. McNichols, "Analyst Coverage and Intangible Assets," Journal of Accounting Research 39 (2001): 1-34

Basu, S. "The Conservatism Principle and The Asymmetric Timeliness of Earnings." Journal of Accounting and Economics 24 (1997): 3-37.

Beaver, W., "The Information Content of Annual Earnings Announcements," Journal of Accounting Research (1968) Supplement: 67-92.

Beaver, W., M. McAnally, and C. Stinson, "The Information Content of Earnings and Prices: A Simultaneous Equation Approach," Journal of Accounting and Economics 23 (1997): 53-81.

Berger, A.N. and G.F. Udell, “Collateral, Loan Quality and Bank Risk,” Journal of Monetary Economics 25 (1990): 21-42.

Blume, M.E., D. Keim, and S. Patel, "Returns and Volatility of Low Grade Bonds," Journal of Finance 46 (1991): 49-74.

Boot, A.W.A. "Relationship Banking: What do we Know?” Journal of Financial Intermediation 9 (2000): 7-25. 
Bradley, M. and M.R. Roberts, "The Structure and Pricing of Corporate Debt Contracts," May 13, 2004, Duke University Working Paper.

Carey, M., M. Post and S. Sharpe, "Does Corporate Lending by Banks and Finance Companies Differ? Evidence on Specialization in Private Debt Contracting," Journal of Finance 53 (1998): 845-878.

Casolaro, L., D. Focarelli and A.F. Pizzolo, "The Pricing Effect of Certification on Bank Loans: Evidence from the Syndicated Credit Market," Working Paper, 2003.

Chambers, D. "The Information Content of Negative Earnings and Its Relation With Initial Loss Persistence.” Working paper, University of Illinois at Urbana-Champaign, 1996.

Cornell, B. and K. Green, "The Investment Performance of Low Grade Funds," Journal of Finance 46 (1991): 29-48.

Dahiya, S., M. Puri and A. Saunders, "Bank Borrowers and Loan Sales: New Evidence on the Uniqueness of Bank Loans," Journal of Business 2004.

Davis, D.W., J. Boatsman and E. Baskin, "On Generalizing Stock Market Research to a Broader Class of Markets,” The Accounting Review 53 (1978): 1-10.

Denis, D.J. and V.T. Mihov, "The Choice Among Bank Debt, Non-Bank Private Debt and Public Debt: Evidence from New Corporate Borrowings," June 2002, Purdue University working paper.

Dennis, S.A. and D.J. Mullineaux, "Syndicated Loans," Journal of Financial Intermediation 9 (2000): 404-426.

Diamond, D. "Monitoring and Reputation: The Choice Between Bank Loans and Privately-placed Debt.” Journal of Political Economy 99 (1991): 689-721.

Dichev, I, and D. Skinner.'Large-sample Evidence on the Debt Covenant Hypothesis." Journal of Accounting Research 40 (2002): 1091-1123.

Easton, P. and M. Zmijewski, "Cross-sectional Variation in the Stock Market Response to Accounting Earnings Announcements," Journal of Accounting and Economics 11 (1989): 117-141.

Foster, G., "Quarterly Accounting Data: Time-series Properties and Predictive-ability Results.” The Accounting Review 52 (1977): 1-21.

Hayn, C. "The Information Content of Losses." Journal of Accounting and Economics 20 (1995): 125-153. 
Handjinicolaou, G. and A. Kalay, "Wealth Redistribution or Changes in Firm Value: An Analysis of Returns to Bondholders and Stockholders Around Dividend Announcements." Journal of Financial Economics 13 (1984):35-63.

Holthausen, R., and R. Leftwich. "The Effect of Bond Rating Changes on Common Stock Prices." Journal of Financial Economics 17 (1986): 57-89.

Hotchkiss, E. and T. Ronen, "The Informational Efficiency of the Corporate Bond Market: An Intraday Analysis," The Review of Financial Studies 15(2002): 1325-1354.

Hotchkiss, E., and D. Strickland, "Does Shareholder Composition Matter? Evidence from the Market Reaction to Corporate Earnings Announcements," Journal of Finance 58 (2003):1469-1498.

Houston, J. and C. James, "Bank Information Monopolies and Mix of Private and Public Debt Claims," Journal of Finance 51 (1996): 1863-1889.

James, C., "Some Evidence of the Uniqueness of Bank Loans, Journal of Financial Economics 19 (1987): 217-235.

James, C. and P. Wier, "Borrowing Relationships, Intermediation, and The Cost of Issuing Public Securities," Journal of Financial Economics 28 (1990): 149-171.

John, K., A.W. Lynch, M. Puri, "Credit Ratings, Collateral and Loan Characteristics: Implications for Yield," 2002, Journal of Business, forthcoming.

Jorgensen, R.D. and J.R. Wingender, Jr., "A Survey on the Dissemination of Earnings Information by Large Firms," Journal of Applied Finance, Spring/Summer 2004, pp. 7784.

Kothari, S. P., "Capital Markets Research in Accounting." Journal of Accounting and Economics 31 (2001): 105-231

Kwan, S., "Firm Specific Information and the Correlation Between Individual Stocks and Bonds," Journal of Financial Economics 40 (1996): 63-80.

Lummer, S.I. and J. McConnell, "Further Evidence on The Bank Lending Process and The Capital-market Response to Bank Loan Agreements," Journal of Financial Economics 25 (1989): 99-122.

Landsman, W.R. and E.L Maydew, "Has the Information Content of Quarterly Earnings Announcements Declined Over the Past Three Decades?" Journal of Accounting Research 40 (2002): 797-808. 
Lev, B. Intangibles - Management, Measurement and Reporting. Brookings Institute, Washington DC, 2001.

Merton, R.C., "On the Pricing of Corporate Debt: The Risk Structure of Interest Rates," Journal of Finance (1974): 449-470.

Miller, S., "The Development of the Leveraged Loan Asset Class," in Bank Loans: Secondary Market and Portfolio Management, Frank J. Fabozzi, editor, Frank J. Fabozzi Associates, New Hope, Pennsylvania: 1998: 1-24.

Oldham, S.D., "The Leveraged Bank Loan Market," in Bank Loans: Secondary Market and Portfolio Management, Frank J. Fabozzi, editor, Frank J. Fabozzi Associates, New Hope, Pennsylvania: 1998: 25-48.

Pennachi, G. "Loan Sales and the Cost of Bank Capital." Journal of Finance 43 (1988): 375-396

Preece, D. and D. Mullineaux, "Monitoring loan renegotiation and firm value: The role of lending syndicates," Journal of Banking and Finance 20 (1996): 577-594.

Press, E. G. and J. Weintrop. "Debt Covenant Disclosures, Information Cost and the Impact of SEC Rule 144A," Journal of Accounting and Public Policy 11 (1992): 67-81.

Reiter, S.A., "The Use of Bond Marker Data in Accounting Research", Journal of Accounting Literature 9 (1990): 183-227.

Saunders, A. and L. Allen, Credit Risk Measurement: New Approaches to Value at Risk and Other Paradigms, second edition, 2002, New York: John Wiley and Sons.

Schwert, W, "Size and Stock Returns, and Other Empirical Regularities," Journal of Financial Economics 12 (1983): 3-13.

Thomas, H. and Z. Wang, "The Integration of Bank Syndication Loan and Junk Bond Markets," Journal of Banking and Finance 28 (2004): 299-329.

Smith, C. "Applications of Options Pricing Analysis." In: Bicksler, J.L. (Ed.), Handbook of Financial Economics. North-Holland, Amsterdam, 1979: 79-121.

Zuckerman, G. and J. Sapsford, "Some Companies Weather Squeeze on Credits - Pinch Could Dilute Impact of Lower Interest Rates," Wall Street Journal, October 29, 2001, p. C1. 


\section{Figure 1}

\section{Mean Portfolio Returns on Syndicated Loans By Type of News}

Mean portfolio loan returns by type of news

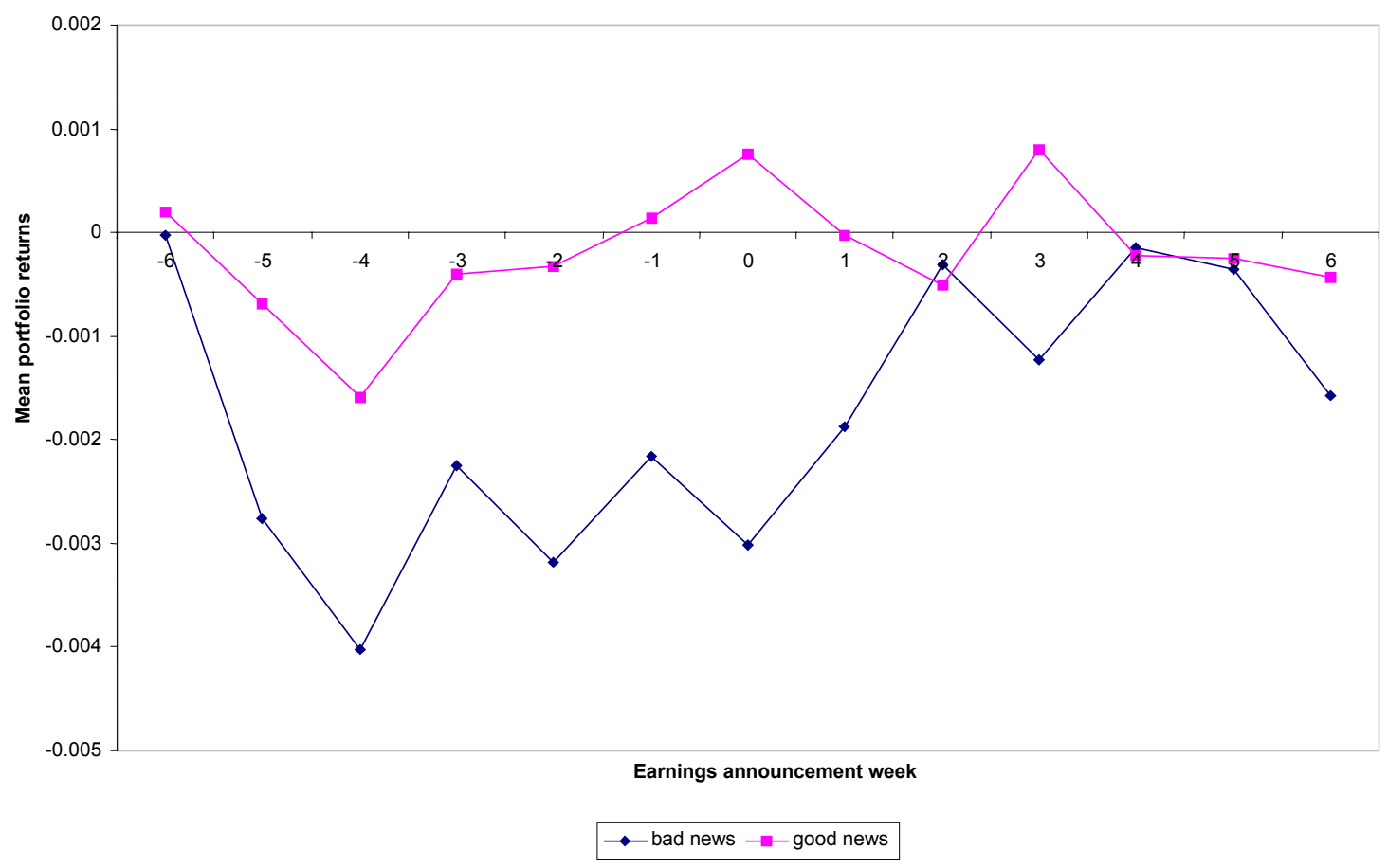


Table 1

Summary statistics

\begin{tabular}{ccccccc}
\hline \multicolumn{7}{c}{ Panel A: Summary Statistics of the Variables Used in the Overall Firms Sample } \\
\hline Variable & $N$ & Mean & Std. dev. & Median & Min & Max \\
\hline$R_{i t}$ & 11034 & -0.0001 & 0.0055 & 0.000 & -0.0458 & 0.0422 \\
MR $_{t}$ & 11034 & 0.0015 & 0.0119 & 0.0012 & -0.0433 & 0.0567 \\
CE $_{i q}$ & 11034 & -0.5433 & 10.1065 & -0.1300 & -363.6700 & 62.2600 \\
SIZE $_{i q}$ & 11034 & 3262.0000 & 8419.0000 & 960.3168 & 0.7181 & 103441.0000 \\
Intangible $_{i}$ & 11034 & 0.3092 & 0.4622 & 0.0000 & 0.0000 & 1.0000 \\
Tobin's $_{i q}$ & 10750 & 0.9674 & 1.6375 & 0.8263 & 0.0790 & 45.8714 \\
RATING $_{i}$ & 11034 & 5.5334 & 0.8817 & 6.0000 & 3.0000 & 7.0000 \\
SPREAD & 11034 & 287.8433 & 111.5056 & 275.0000 & 30.0000 & 550.0000 \\
NOQUOTES $_{i t}$ & 11034 & 8.9282 & 5.1928 & 6.0000 & 4.0000 & 28.0000 \\
DISTRESS $_{i q}$ & 11034 & 0.1760 & 0.3808 & 0.0000 & 0.0000 & 1.0000 \\
COVENANT $_{i}$ & 11034 & 0.8617 & 0.3451 & 1.0000 & 0.0000 & 1.0000 \\
SECURED $_{i}$ & 11034 & 0.8834 & 0.3210 & 1.0000 & 0.0000 & 1.0000 \\
MATU $_{i}$ & 11034 & 6.2407 & 1.5694 & 6.6400 & 1.0000 & 9.2200 \\
LOANSIZE $_{i}$ & 11034 & 561.4557 & 2024.0000 & 270.0000 & 40.0000 & 25000.0000
\end{tabular}

Panel B: Summary Statistics of the Variables Used in the Bad News Firms Sample

\begin{tabular}{ccccccc}
\hline Variable & $N$ & Mean & Std. dev. & Median & Min & Max \\
\hline$R_{i t}$ & 5031 & -0.0004 & 0.0063 & 0.0000 & -0.0458 & 0.0414 \\
MR $_{t}$ & 5031 & 0.0012 & 0.0122 & 0.0010 & -0.0433 & 0.0567 \\
CE $_{i q}$ & 5031 & -1.0166 & 13.9414 & -0.4000 & -363.6700 & 62.2600 \\
SIZE $_{i q}$ & 5031 & 3736.0000 & 10072.0000 & 907.4464 & 1.1250 & 103441.0000 \\
Intangible $_{i}$ & 5031 & 0.3492 & 0.4768 & 0.0000 & 0.0000 & 1.0000 \\
Tobin's $_{i q}$ & 4864 & 0.9831 & 2.0738 & 0.8408 & 0.2387 & 45.8714 \\
RATING $_{i}$ & 5031 & 5.6404 & 0.9053 & 6.0000 & 3.0000 & 7.0000 \\
SPREAD $_{i t}$ & 5031 & 296.2648 & 115.6560 & 300.0000 & 30.0000 & 550.0000 \\
NOQUOTES $_{i t}$ & 5031 & 9.1544 & 5.3597 & 8.0000 & 4.0000 & 28.0000 \\
DISTRESS $_{i q}$ & 5031 & 0.1898 & 0.3922 & 0.0000 & 0.0000 & 1.0000 \\
COVENANT & 5031 & 0.8511 & 0.3560 & 1.0000 & 0.0000 & 1.0000 \\
SECURED $_{i}$ & 5031 & 0.8734 & 0.3326 & 1.0000 & 0.0000 & 1.0000 \\
MATU $_{i}$ & 5031 & 6.2227 & 1.6575 & 6.8500 & 1.0000 & 9.2200 \\
LOANSIZE $_{i}$ & 5031 & 672.5747 & 2463.0000 & 285.0000 & 40.0000 & 25000.0000
\end{tabular}

Panel C: Summary Statistics of the Variables Used in the Good News Firms Sample

\begin{tabular}{ccccccc}
\hline Variable & $N$ & Mean & Std. dev. & Median & Min & Max \\
\hline$R_{i t}$ & 6003 & -0.0001 & 0.0046 & 0.0000 & -0.0439 & 0.0422 \\
MR $_{t}$ & 6003 & 0.0018 & 0.0117 & 0.0013 & -0.0433 & 0.0567 \\
CE $_{i q}$ & 6003 & -0.1466 & 4.9522 & 0.1100 & -85.0000 & 30.0000 \\
SIZE $_{i q}$ & 6003 & 2864.0000 & 6703.0000 & 993.1400 & 0.7181 & 91561.0000 \\
Intangible $_{i}$ & 6003 & 0.2757 & 0.4469 & 0.0000 & 0.0000 & 1.0000 \\
${\text { Tobin's } q_{i q}}_{\text {RATING }}$ & 5886 & 0.9545 & 1.1592 & 0.8158 & 0.0790 & 23.5694 \\
SPREAD $_{i t}$ & 6003 & 5.4438 & 0.8511 & 5.000 & 3.000 & 7.000 \\
NOQUOTES $_{i t}$ & 6003 & 280.7854 & 107.4067 & 275.0000 & 30.0000 & 550.0000 \\
DISTRESS $_{i q}$ & 6003 & 8.7386 & 5.0413 & 6.0000 & 4.0000 & 26.0000 \\
COVENANT & 6003 & 0.1644 & 0.3707 & 0.0000 & 0.0000 & 1.0000 \\
SECURED $_{i}$ & 6003 & 0.8707 & 0.3355 & 1.0000 & 0.0000 & 1.0000 \\
MATU $_{i}$ & 6003 & 0.8917 & 0.3108 & 1.0000 & 0.0000 & 1.0000 \\
LOANIZE $_{i}$ & 6003 & 6.2558 & 1.4914 & 6.5200 & 1.0000 & 9.2200 \\
\hline
\end{tabular}




\begin{tabular}{|c|c|c|}
\hline Variable & T-test & F-Test \\
\hline$R_{i t}$ & $2.66^{* * * *}$ & $1.88^{* * *}$ \\
\hline$M R_{t}$ & $2.57^{* * * *}$ & $1.08^{* * *}$ \\
\hline$C E_{i q}$ & $4.51^{* * *}$ & $7.93^{* * *}$ \\
\hline$S I Z E_{i q}$ & $-5.42^{* * *}$ & $2.26^{* * *}$ \\
\hline Intangible $_{i}$ & $-8.35^{* * *}$ & $1.14^{* * *}$ \\
\hline Tobin's $q_{i q}$ & 0.90 & $3.20^{* * *}$ \\
\hline $\operatorname{RATING}_{i}$ & $-11.74^{* * *}$ & $1.13^{* * *}$ \\
\hline$S P R E A D_{i t}$ & $-3.66^{* * *}$ & $1.20^{* * *}$ \\
\hline NOQUOTES $S_{i t}$ & $-3.73^{* * *}$ & $1.06^{* *}$ \\
\hline DISTRESS $_{i q}$ & $-3.49^{* * *}$ & $1.12^{* * *}$ \\
\hline COVENANT & $2.97^{* * *}$ & $1.13^{* * *}$ \\
\hline SECURED & $2.99^{* * *}$ & $1.15^{* * *}$ \\
\hline$M A T U_{i}$ & $2.77^{* * *}$ & $1.34^{* * *}$ \\
\hline LOANSIZE $_{i}$ & $-9.82^{* * *}$ & $1.18^{* * *}$ \\
\hline
\end{tabular}

Notes: This table reports summary statistics for the 11034 firm/loan-quarter observations over the period 1998-2002 used in the overall firms' sample, and in both good/bad news firms, and the comparison between the two groups (good-bad). $R_{i t}$ is the weekly return on syndicated loan facility $i$ in week $t . M R_{t}$ is return on $\mathrm{S} \& \mathrm{P}$ syndicated loan index in week $t . C E_{i q}$ is the percentage change in quarterly earnings measured by changes in earnings for quarter $q$ from the current year to the prior year for firm $i$. SIZE $E_{i q}$ is firm size, measured by the market capitalization (in millions of dollars)at the beginning of quarter $q$ for firm $i$. Intangible $i$ is an indicator variable that takes the value of one is firm $i$ is in an intangible-intensive industry, and zero otherwise. Tobin's $q_{i q}$ is measured by the market value of firm $i$ 's assets over its book value of assets at the beginning of the quarter $q . R_{A T I N G_{i}}$ is an indicator variable coded into 1 through 7 to represent Moody's senior debt ratings of Aaa, Aa, A, Baa, Ba, B and lower than $\mathrm{B}$ on facility $i$. SPREAD $D_{i t}$ is all-in spread, measured by the basis point spread over LIBOR, inclusive of all fees for facility $i$ at week t. NOQUOTES $S_{i t}$ is the total number of weekly quotes on facility $i$ at week $t$. DISTRESS $S_{i q}$ is distressed loan indicator that takes the value of one if the price of the loan is less than 80 at week -5 of earnings announcement for quarter $q$ and zero otherwise. $C O V E N A N T_{i}$ is an indicator variable that equals one if a loan has financial covenant and zero otherwise. $S E C U R E D_{i}$ equals one if a loan is secured and zero otherwise. $M A T U_{i}$ measures the maturity of the loan in terms of the number of years from the loan origination to its maturity. $L O A N S I Z E_{i}$ is the size of the loan at its origination, it is expressed in thousands of dollars. The superscript asterisks *,**,*** denote significance at or below the $0.10,0.05,0.01$ level, respectively, based on a two-tailed (T-test) or a one-tailed (F-test) test of significance. 
Table 2

\section{OLS Regressions of Weekly Syndicated Loan Returns in a Window of $[-5,0]$ Weeks Around Quarterly Earnings Announcement Dates}

Model: $R_{i t}=\alpha+\beta_{1} M R_{t}+\beta_{2} C_{i q}+\beta_{3} S_{I Z E_{i q}}+\beta_{4}$ RATING $_{i}+\beta_{5}$ SSPREAD $_{i t}+\beta_{6}$ NOQUOTE $_{i t}$

$+\beta_{7}$ DISTRESS $_{i t}+\beta_{8}$ COVENANT $_{i}+\beta_{9}$ SECURED $_{i}+\beta_{10}$ MATU $_{i}+\beta_{11}$ LOANSIZE $_{i}$

$+\beta_{12} K_{i t}+\varepsilon_{i t}$

\begin{tabular}{|c|c|c|c|c|c|c|c|}
\hline & $\begin{array}{l}\text { Predicted } \\
\text { Sign }\end{array}$ & (1) & (2) & (3) & (4) & (5) & (6) \\
\hline MR & + & $\begin{array}{l}0.0088 \\
(1.99)^{* *}\end{array}$ & $\begin{array}{l}0.0087 \\
(1.97)^{* *}\end{array}$ & $\begin{array}{l}0.0088 \\
(1.99)^{* *}\end{array}$ & $\begin{array}{l}0.0089 \\
(2.00)^{* *}\end{array}$ & $\begin{array}{l}0.0089 \\
(1.99)^{* *}\end{array}$ & $\begin{array}{l}0.0086 \\
(1.93)^{*}\end{array}$ \\
\hline $\begin{array}{l}\text { Percentage Change in } \\
\text { Earnings }\end{array}$ & + & $\begin{array}{l}0.0000 \\
(1.25)\end{array}$ & $\begin{array}{l}0.0000 \\
(1.25)\end{array}$ & $\begin{array}{l}0.0000 \\
(1.25)\end{array}$ & $\begin{array}{l}0.0000 \\
(1.26)\end{array}$ & $\begin{array}{l}0.0000 \\
(1.24)\end{array}$ & $\begin{array}{l}0.0000 \\
(1.25)\end{array}$ \\
\hline Log of Firm Size & ? & $\begin{array}{l}-0.0001 \\
(-2.22)^{* *}\end{array}$ & $\begin{array}{l}-0.0001 \\
(-2.23)^{* *}\end{array}$ & $\begin{array}{l}-0.0001 \\
(-2.22)^{* *}\end{array}$ & $\begin{array}{l}-0.0001 \\
(-2.21)^{* *}\end{array}$ & $\begin{array}{l}-0.0001 \\
(-2.21)^{* *}\end{array}$ & $\begin{array}{l}-0.0001 \\
(-2.34)^{* *}\end{array}$ \\
\hline Loan Rate & - & $\begin{array}{l}-0.0003 \\
(-4.39)^{* * *}\end{array}$ & $\begin{array}{l}-0.0003 \\
(-4.38)^{* * *}\end{array}$ & $\begin{array}{l}-0.0003 \\
(-4.39)^{* * *}\end{array}$ & $\begin{array}{l}-0.0003 \\
(-4.39)^{* * *}\end{array}$ & $\begin{array}{l}-0.0003 \\
(-4.40)^{* * *}\end{array}$ & $\begin{array}{l}-0.0003 \\
(-4.53)^{* * *}\end{array}$ \\
\hline $\begin{array}{l}\text { Log of All-In Spread } \\
\text { (Basis Points over } \\
\text { LIBOR) }\end{array}$ & $?$ & $\begin{array}{l}-0.0004 \\
(-2.29)^{* *}\end{array}$ & $\begin{array}{l}-0.0004 \\
(-2.31)^{* *}\end{array}$ & $\begin{array}{l}-0.0004 \\
(-2.29)^{* *}\end{array}$ & $\begin{array}{l}-0.0004 \\
(-2.28)^{* *}\end{array}$ & $\begin{array}{l}-0.0004 \\
(-2.28)^{* *}\end{array}$ & $\begin{array}{l}-0.0003 \\
(-2.18)^{* *}\end{array}$ \\
\hline $\begin{array}{l}\text { Log of Number of } \\
\text { Quotes }\end{array}$ & - & $\begin{array}{l}-0.0003 \\
(-3.08)^{* *}\end{array}$ & $\begin{array}{l}-0.0003 \\
(-3.08)^{* *}\end{array}$ & $\begin{array}{l}-0.0003 \\
(-3.08)^{* *}\end{array}$ & $\begin{array}{l}-0.0003 \\
(-3.08)^{* *}\end{array}$ & $\begin{array}{l}-0.0003 \\
(-3.08)^{* *}\end{array}$ & $\begin{array}{l}-0.0003 \\
(-3.18)^{* *}\end{array}$ \\
\hline $\begin{array}{l}\text { Distressed Loan } \\
\text { Indicator }\end{array}$ & - & $\begin{array}{l}-0.0000 \\
(-0.21)\end{array}$ & $\begin{array}{l}-0.0000 \\
(-0.22)\end{array}$ & $\begin{array}{l}-0.0000 \\
(-0.12)\end{array}$ & $\begin{array}{l}-0.0000 \\
(-0.14)\end{array}$ & $\begin{array}{l}-0.0000 \\
(-0.11)\end{array}$ & $\begin{array}{l}-0.0000 \\
(-0.15)\end{array}$ \\
\hline $\begin{array}{l}\text { Financial Covenants } \\
\text { Indicator }\end{array}$ & $?$ & $\begin{array}{l}-0.0001 \\
(-0.85)\end{array}$ & $\begin{array}{l}-0.0001 \\
(-0.83)\end{array}$ & $\begin{array}{l}-0.0001 \\
(-0.84)\end{array}$ & $\begin{array}{l}-0.0001 \\
(-0.84)\end{array}$ & $\begin{array}{l}-0.0001 \\
(-0.85)\end{array}$ & $\begin{array}{l}-0.0001 \\
(-0.66)\end{array}$ \\
\hline $\begin{array}{l}\text { Secured Loan } \\
\text { Indicator }\end{array}$ & + & $\begin{array}{l}0.0001 \\
(0.29)\end{array}$ & $\begin{array}{l}0.0001 \\
(0.30)\end{array}$ & $\begin{array}{l}0.0001 \\
(0.29)\end{array}$ & $\begin{array}{l}0.0001 \\
(0.30)\end{array}$ & $\begin{array}{l}0.0001 \\
(0.29)\end{array}$ & $\begin{array}{l}0.0001 \\
(0.42)\end{array}$ \\
\hline $\begin{array}{l}\text { Log of Maturity in } \\
\text { Years }\end{array}$ & + & $\begin{array}{l}-0.0002 \\
(-0.88)\end{array}$ & $\begin{array}{l}-0.0002 \\
(-0.88)\end{array}$ & $\begin{array}{l}-0.0002 \\
(-0.88)\end{array}$ & $\begin{array}{l}-0.0002 \\
(-0.88)\end{array}$ & $\begin{array}{l}-0.0002 \\
(-0.88)\end{array}$ & $\begin{array}{l}-0.0002 \\
(-0.90)\end{array}$ \\
\hline Log of Loan Size & - & $\begin{array}{l}-0.0003 \\
(-3.57)^{* * *}\end{array}$ & $\begin{array}{l}-0.0003 \\
(-3.58)^{* * * *}\end{array}$ & $\begin{array}{l}-0.0003 \\
(-3.57)^{* * *}\end{array}$ & $\begin{array}{l}-0.0003 \\
(-3.57)^{* * *}\end{array}$ & $\begin{array}{l}-0.0003 \\
(-3.57)^{* * * *}\end{array}$ & $\begin{array}{l}-0.0003 \\
(-3.41)^{* * *}\end{array}$ \\
\hline Week -5 & $?$ & $\begin{array}{l}-0.0002 \\
(-1.22)\end{array}$ & & & & & \\
\hline Week -4 & $?$ & & $\begin{array}{l}-0.0006 \\
(-2.54)^{* *}\end{array}$ & & & & \\
\hline Week -3 & ? & & & $\begin{array}{l}-0.0002 \\
(-1.07)\end{array}$ & & & \\
\hline Week -2 & ? & & & & $\begin{array}{l}-0.0004 \\
(-1.86)^{*}\end{array}$ & & \\
\hline Week -1 & $?$ & & & & & $\begin{array}{l}-0.0001 \\
(-0.45)\end{array}$ & \\
\hline Week 0 & $?$ & & & & & & $\begin{array}{l}0.0002 \\
(0.82)\end{array}$ \\
\hline Observations & & 11034 & 11034 & 11034 & 11034 & 11034 & 11034 \\
\hline Adjusted $\mathrm{R}^{2}$ & & 0.0079 & 0.0087 & 0.0078 & 0.0081 & 0.0078 & 0.0079 \\
\hline
\end{tabular}

Notes: This table reports regression results for testing the information content of quarterly earnings on syndicated loan returns using pooled cross-sectional, time-series ordinary least squares for 11034 firmquarter observations over -5 to 0 weeks of each quarterly earnings announcement during 1998-2002 period. $R_{i t}$ is the weekly return on syndicated loan facility $i$ in week $t . M R_{t}$ is return on S\&P syndicated loan index in week $t$. $C E_{i q}$ is the percentage change in quarterly earnings measured by changes in earnings 
for quarter $q$ from the current year to the prior year for firm $i . S I Z E_{i q}$ is firm size, measured by the market capitalization (in millions of dollars)at the beginning of quarter $q$ for firm $i . R A T I N G_{i}$ is an indicator variable coded into 1 through 7 to represent Moody's senior debt ratings of Aaa, Aa, A, Baa, Ba, B and lower than B on facility $i$. SPREAD $D_{i t}$ is all-in spread, measured by the basis point spread over LIBOR, inclusive of all fees for facility $i$ at week $t$. NOQUOTES $S_{i t}$ is the total number of weekly quotes on facility $i$ at week $t$. DISTRESS $S_{i q}$ is distressed loan indicator that takes the value of one if the price of the loan is less than 80 at week -5 of earnings announcement at quarter $q$ and zero otherwise. COVENANT $i$ is an indicator variable that equals one if a loan has financial covenant and zero otherwise. $S E C U R E D_{i}$ equals one if a loan is secured and zero otherwise. $M A T U_{i}$ measures the maturity of the loan in terms of the number of years from the loan origination to its maturity. $\operatorname{LOANSIZE}_{i}$ is the size of the loan at its origination, it is expressed in thousands of dollars. $K_{i t}$ is a dummy variable that equal $1 \mathrm{~s}$ if the observed loan return at week $t$ of firm $i$ is in $K$ weeks prior to its quarterly earnings announcement date, and zero otherwise. Regression is repeated for $K=[-5,0]$. Regressions also contain year indicators. T-tests are in the parenthesis below the coefficient, and p-values are calculated using White's standard errors. The superscript asterisks *, **, *** denote significance at or below the $0.10,0.05,0.01$ level, respectively, based on a two-tailed (where sign is not predicted) or a one-tailed (where sign is predicted) test of significance. 
Table 3

OLS Regressions of Weekly Syndicated Loan Returns in a Window of $[-5,0]$ Weeks Around Quarterly Earnings Announcement Dates - By Type of News

$$
\begin{aligned}
\text { Model: } R_{i t}= & \alpha+\beta_{1} \text { MR }_{t}+\beta_{2} \text { CE }_{i q}+\beta_{3} \text { SIZE }_{i q}+\beta_{4} \text { RATING }_{i}+\beta_{5} \text { LSPREAD }_{i t}+\beta_{6} \text { NOQUOTE }_{i t} \\
& +\beta_{7} \text { DISTRESS }_{i t}+\beta_{8} \text { COVENANT }_{i}+\beta_{9} \text { SECURED }_{i}+\beta_{10} \text { MATU }_{i}+\beta_{1 I} \text { LOANSIZE }_{i} \\
& +\beta_{12} K_{i t}+\varepsilon_{i t}
\end{aligned}
$$

\begin{tabular}{|c|c|c|c|c|c|c|c|}
\hline \multicolumn{8}{|c|}{ Panel A: Bad News Firms } \\
\hline & $\begin{array}{l}\text { Predicted } \\
\text { Sign }\end{array}$ & (1) & (2) & (3) & (4) & (5) & (6) \\
\hline MR & + & $\begin{array}{l}0.0110 \\
(1.62)\end{array}$ & $\begin{array}{l}0.0111 \\
(1.63)\end{array}$ & $\begin{array}{l}0.0108 \\
(1.58)\end{array}$ & $\begin{array}{l}0.0108 \\
(1.58)\end{array}$ & $\begin{array}{l}0.0110 \\
(1.62)\end{array}$ & $\begin{array}{l}0.0108 \\
(1.58)\end{array}$ \\
\hline $\begin{array}{l}\text { Percentage Change in } \\
\text { Earnings }\end{array}$ & + & $\begin{array}{l}0.0000 \\
(0.70)\end{array}$ & $\begin{array}{l}0.0000 \\
(0.71)\end{array}$ & $\begin{array}{l}0.0000 \\
(0.71)\end{array}$ & $\begin{array}{l}0.0000 \\
(0.71)\end{array}$ & $\begin{array}{l}0.0000 \\
(0.69)\end{array}$ & $\begin{array}{l}0.0000 \\
(0.70)\end{array}$ \\
\hline Log of Firm Size & $?$ & $\begin{array}{l}-0.0002 \\
(-3.44)^{* * *}\end{array}$ & $\begin{array}{l}-0.0002 \\
(-3.42)^{* * *}\end{array}$ & $\begin{array}{l}-0.0002 \\
(-3.41)^{* * *}\end{array}$ & $\begin{array}{l}-0.0002 \\
(-3.39)^{* * *}\end{array}$ & $\begin{array}{l}-0.0002 \\
(-3.39)^{* * *}\end{array}$ & $\begin{array}{l}-0.0002 \\
(-3.39)^{* * *}\end{array}$ \\
\hline Loan Rate & - & $\begin{array}{l}-0.0005 \\
(-4.36)^{* * *}\end{array}$ & $\begin{array}{l}-0.0005 \\
(-4.38)^{* * *}\end{array}$ & $\begin{array}{l}-0.0005 \\
(-4.38)^{* * *}\end{array}$ & $\begin{array}{l}-0.0005 \\
(-4.38)^{* * *}\end{array}$ & $\begin{array}{l}-0.0005 \\
(-4.38)^{* * *}\end{array}$ & $\begin{array}{l}-0.0005 \\
(-4.38)^{* * *}\end{array}$ \\
\hline $\begin{array}{l}\text { Log of All-In Spread } \\
\text { (Basis Points over } \\
\text { LIBOR) }\end{array}$ & $?$ & $\begin{array}{l}-0.0001 \\
(-0.49)\end{array}$ & $\begin{array}{l}-0.0001 \\
(-0.48)\end{array}$ & $\begin{array}{l}-0.0001 \\
(-0.48)\end{array}$ & $\begin{array}{l}-0.0001 \\
(-0.47)\end{array}$ & $\begin{array}{l}-0.0001 \\
(-0.46)\end{array}$ & $\begin{array}{l}-0.0001 \\
(-0.47)\end{array}$ \\
\hline $\begin{array}{l}\text { Log of Number of } \\
\text { Quotes }\end{array}$ & - & $\begin{array}{l}-0.0004 \\
(-2.30)^{* *}\end{array}$ & $\begin{array}{l}-0.0004 \\
(-2.32)^{* *}\end{array}$ & $\begin{array}{l}-0.0004 \\
(-2.33)^{* *}\end{array}$ & $\begin{array}{l}-0.0004 \\
(-2.33)^{* *}\end{array}$ & $\begin{array}{l}-0.0004 \\
(-2.33)^{* *}\end{array}$ & $\begin{array}{l}-0.0004 \\
(-2.34)^{* *}\end{array}$ \\
\hline $\begin{array}{l}\text { Distressed Loan } \\
\text { Indicator }\end{array}$ & - & $\begin{array}{l}-0.0001 \\
(-0.29)\end{array}$ & $\begin{array}{l}-0.0000 \\
(-0.16)\end{array}$ & $\begin{array}{l}-0.0001 \\
(-0.12)\end{array}$ & $\begin{array}{l}-0.0000 \\
(-0.12)\end{array}$ & $\begin{array}{l}-0.0000 \\
(-0.11)\end{array}$ & $\begin{array}{l}-0.0000 \\
(-0.10)\end{array}$ \\
\hline $\begin{array}{l}\text { Financial Covenants } \\
\text { Indicator }\end{array}$ & - & $\begin{array}{l}-0.0004 \\
(-1.82)^{*}\end{array}$ & $\begin{array}{l}-0.0005 \\
(-1.81)^{*}\end{array}$ & $\begin{array}{l}-0.0005 \\
(-1.81)^{*}\end{array}$ & $\begin{array}{l}-0.0005 \\
(-1.82)^{*}\end{array}$ & $\begin{array}{l}-0.0005 \\
(-1.82)^{*}\end{array}$ & $\begin{array}{l}-0.0005 \\
(-1.82)^{*}\end{array}$ \\
\hline $\begin{array}{l}\text { Secured Loan } \\
\text { Indicator }\end{array}$ & + & $\begin{array}{l}0.0003 \\
(0.66)\end{array}$ & $\begin{array}{l}0.0003 \\
(0.65)\end{array}$ & $\begin{array}{l}0.0003 \\
(0.65)\end{array}$ & $\begin{array}{l}0.0003 \\
(0.65)\end{array}$ & $\begin{array}{l}0.0003 \\
(0.66)\end{array}$ & $\begin{array}{l}0.0003 \\
(0.65)\end{array}$ \\
\hline $\begin{array}{l}\text { Log of Maturity in } \\
\text { Years }\end{array}$ & + & $\begin{array}{l}0.0001 \\
(0.21)\end{array}$ & $\begin{array}{l}0.0001 \\
(0.22)\end{array}$ & $\begin{array}{l}0.0001 \\
(0.21)\end{array}$ & $\begin{array}{l}0.0001 \\
(0.22)\end{array}$ & $\begin{array}{l}0.0001 \\
(0.22)\end{array}$ & $\begin{array}{l}0.0001 \\
(0.22)\end{array}$ \\
\hline Log of Loan Size & - & $\begin{array}{l}-0.0001 \\
(-0.88)\end{array}$ & $\begin{array}{l}-0.0001 \\
(-0.88)\end{array}$ & $\begin{array}{l}-0.0001 \\
(-0.86)\end{array}$ & $\begin{array}{l}-0.0001 \\
(-0.86)\end{array}$ & $\begin{array}{l}-0.0001 \\
(-0.87)\end{array}$ & $\begin{array}{l}-0.0001 \\
(-0.86)\end{array}$ \\
\hline Week -5 & - & $\begin{array}{l}-0.0007 \\
(-2.26)^{* *}\end{array}$ & & & & & \\
\hline Week -4 & - & & $\begin{array}{l}-0.0008 \\
(-3.24)^{* * *}\end{array}$ & & & & \\
\hline Week -3 & - & & & $\begin{array}{l}-0.0004 \\
(-1.41)\end{array}$ & & & \\
\hline Week -2 & - & & & & $\begin{array}{l}-0.0004 \\
(-1.47)\end{array}$ & & \\
\hline Week -1 & - & & & & & $\begin{array}{l}-0.0002 \\
(0.73)\end{array}$ & \\
\hline Week 0 & - & & & & & & $\begin{array}{l}0.0002 \\
(0.73)\end{array}$ \\
\hline Observations & & 5031 & 5031 & 5031 & 5031 & 5031 & 5031 \\
\hline Adjusted $\mathrm{R}^{2}$ & & 0.0131 & 0.0134 & 0.0125 & 0.0125 & 0.0122 & 0.0122 \\
\hline
\end{tabular}


Panel B: Good News Firms

\begin{tabular}{|c|c|c|c|c|c|c|c|}
\hline & $\begin{array}{l}\text { Predicted } \\
\text { Sign }\end{array}$ & (1) & (2) & (3) & (4) & (5) & (6) \\
\hline MR & + & $\begin{array}{l}0.0085 \\
(1.50)\end{array}$ & $\begin{array}{l}0.0083 \\
(1.46)\end{array}$ & $\begin{array}{l}0.0084 \\
(1.49)\end{array}$ & $\begin{array}{l}0.0085 \\
(1.51)\end{array}$ & $\begin{array}{l}0.0085 \\
(1.50)\end{array}$ & $\begin{array}{l}0.0083 \\
(1.49)\end{array}$ \\
\hline $\begin{array}{l}\text { Percentage Change in } \\
\text { Earnings }\end{array}$ & + & $\begin{array}{l}0.0000 \\
(0.35)\end{array}$ & $\begin{array}{l}0.0000 \\
(0.34)\end{array}$ & $\begin{array}{l}0.0000 \\
(0.35)\end{array}$ & $\begin{array}{l}0.0000 \\
(0.35)\end{array}$ & $\begin{array}{l}0.0000 \\
(0.35)\end{array}$ & $\begin{array}{l}0.0000 \\
(0.41)\end{array}$ \\
\hline Log of Firm Size & $?$ & $\begin{array}{l}-0.0000 \\
(-0.28)\end{array}$ & $\begin{array}{l}-0.0000 \\
(-0.29)\end{array}$ & $\begin{array}{l}-0.0000 \\
(-0.28)\end{array}$ & $\begin{array}{l}-0.0000 \\
(-0.29)\end{array}$ & $\begin{array}{l}-0.0000 \\
(-0.28)\end{array}$ & $\begin{array}{l}-0.0000 \\
(-0.15)\end{array}$ \\
\hline Loan Rate & - & $\begin{array}{l}-0.0001 \\
(-1.50)\end{array}$ & $\begin{array}{l}-0.0001 \\
(-1.48)\end{array}$ & $\begin{array}{l}-0.0001 \\
(-1.50)\end{array}$ & $\begin{array}{l}-0.0001 \\
(-1.49)\end{array}$ & $\begin{array}{l}-0.0001 \\
(-1.50)\end{array}$ & $\begin{array}{l}-0.0001 \\
(-1.35)\end{array}$ \\
\hline $\begin{array}{l}\text { Log of All-In Spread } \\
\text { (Basis Points over } \\
\text { LIBOR) }\end{array}$ & $?$ & $\begin{array}{l}-0.0004 \\
(-2.12)^{* *}\end{array}$ & $\begin{array}{l}-0.0004 \\
(-2.13)^{* *}\end{array}$ & $\begin{array}{l}-0.0004 \\
(-2.12)^{* *}\end{array}$ & $\begin{array}{l}-0.0004 \\
(-2.12)^{* *}\end{array}$ & $\begin{array}{l}-0.0004 \\
(-2.12)^{* *}\end{array}$ & $\begin{array}{l}-0.0004 \\
(-1.90)^{*}\end{array}$ \\
\hline $\begin{array}{l}\text { Log of Number of } \\
\text { Quotes }\end{array}$ & - & $\begin{array}{l}-0.0002 \\
(-1.13)\end{array}$ & $\begin{array}{l}-0.0002 \\
(-1.13)\end{array}$ & $\begin{array}{l}-0.0002 \\
(-1.13)\end{array}$ & $\begin{array}{l}-0.0002 \\
(-1.13)\end{array}$ & $\begin{array}{l}-0.0002 \\
(-1.13)\end{array}$ & $\begin{array}{l}-0.0002 \\
(-1.20)\end{array}$ \\
\hline $\begin{array}{l}\text { Distressed Loan } \\
\text { Indicator }\end{array}$ & - & $\begin{array}{l}-0.0000 \\
(-0.21)\end{array}$ & $\begin{array}{l}-0.0001 \\
(-0.31)\end{array}$ & $\begin{array}{l}-0.0000 \\
(-0.24)\end{array}$ & $\begin{array}{l}-0.0000 \\
(-0.25)\end{array}$ & $\begin{array}{l}-0.0000 \\
(-0.24)\end{array}$ & $\begin{array}{l}-0.0000 \\
(-0.02)\end{array}$ \\
\hline $\begin{array}{l}\text { Financial Covenants } \\
\text { Indicator }\end{array}$ & + & $\begin{array}{l}0.0002 \\
(1.04)\end{array}$ & $\begin{array}{l}0.0002 \\
(1.04)\end{array}$ & $\begin{array}{l}0.0002 \\
(1.04)\end{array}$ & $\begin{array}{l}0.0002 \\
(1.04)\end{array}$ & $\begin{array}{l}0.0002 \\
(1.04)\end{array}$ & $\begin{array}{l}0.0002 \\
(1.13)\end{array}$ \\
\hline $\begin{array}{l}\text { Secured Loan } \\
\text { Indicator }\end{array}$ & + & $\begin{array}{l}0.0003 \\
(0.84)\end{array}$ & $\begin{array}{l}0.0003 \\
(0.84)\end{array}$ & $\begin{array}{l}0.0003 \\
(0.84)\end{array}$ & $\begin{array}{l}0.0003 \\
(0.84)\end{array}$ & $\begin{array}{l}0.0003 \\
(0.84)\end{array}$ & $\begin{array}{l}0.0003 \\
(0.90)\end{array}$ \\
\hline $\begin{array}{l}\text { Log of Maturity in } \\
\text { Years }\end{array}$ & + & $\begin{array}{l}-0.0002 \\
(-0.61)\end{array}$ & $\begin{array}{l}-0.0002 \\
(-0.61)\end{array}$ & $\begin{array}{l}-0.0002 \\
(-0.62)\end{array}$ & $\begin{array}{l}-0.0002 \\
(-0.61)\end{array}$ & $\begin{array}{l}-0.0002 \\
(-0.61)\end{array}$ & $\begin{array}{l}-0.0002 \\
(-0.88)\end{array}$ \\
\hline Log of Loan Size & - & $\begin{array}{l}-0.0004 \\
(-3.56)^{* * *}\end{array}$ & $\begin{array}{l}-0.0004 \\
(-3.57)^{* * *}\end{array}$ & $\begin{array}{l}-0.0004 \\
(-3.56)^{* * *}\end{array}$ & $\begin{array}{l}-0.0004 \\
(-3.56)^{* * *}\end{array}$ & $\begin{array}{l}-0.0004 \\
(-3.56)^{* * *}\end{array}$ & $\begin{array}{l}-0.0003 \\
(-3.29)^{* * *}\end{array}$ \\
\hline Week -5 & + & $\begin{array}{l}0.0001 \\
(0.30)\end{array}$ & & & & & \\
\hline Week -4 & + & & $\begin{array}{l}-0.0004 \\
(-1.57)\end{array}$ & & & & \\
\hline Week -3 & + & & & $\begin{array}{l}0.0001 \\
(0.43)\end{array}$ & & & \\
\hline Week -2 & + & & & & $\begin{array}{l}-0.0001 \\
(-0.47)\end{array}$ & & \\
\hline Week -1 & + & & & & & $\begin{array}{l}-0.0000 \\
(-0.18)\end{array}$ & \\
\hline Week 0 & + & & & & & & $\begin{array}{l}-0.0002 \\
(0.73)\end{array}$ \\
\hline Observations & & 6003 & 6003 & 6003 & 6003 & 6003 & 6003 \\
\hline Adjusted $\mathrm{R}^{2}$ & & 0.0031 & 0.0035 & 0.0031 & 0.0031 & 0.0031 & 0.0032 \\
\hline
\end{tabular}

Notes: This table reports regression results for testing the information content of quarterly earnings on syndicated loan returns using pooled cross-sectional, time-series ordinary least squares for good/bad news firms over -5 to 0 weeks of each quarterly earnings announcement during 1998-2002 period, respectively. Good/Bad news firms are defined as whether change in quarterly earnings for the same quarter from year $t-l$ to year $t$ is no less than/less than zero. $R_{i t}$ is the weekly return on syndicated loan facility $i$ in week $t$. $M R_{t}$ is return on $\mathrm{S} \& \mathrm{P}$ syndicated loan index in week $t . C E_{i q}$ is the percentage change in quarterly earnings measured by changes in earnings for quarter $q$ from the current year to the prior year for firm $i$. SIZE $i q$ is firm size, measured by the market capitalization (in millions of dollars)at the beginning of quarter $q$ for firm $i$. Intangible $e_{i}$ is an indicator variable that takes the value of one is firm $i$ is in an intangible-intensive industry, and zero otherwise. $R A T I N G_{i}$ is an indicator variable coded into 1 through 7 to represent Moody's senior debt ratings of Aaa, Aa, A, Baa, Ba, B and lower than B on facility $i$. SPREAD it is all-in spread, measured by the basis point spread over LIBOR, inclusive of all fees for facility $i$ at week $t$. 
NOQUOTES $S_{i t}$ is the total number of weekly quotes on facility $i$ at week $t$. DISTRESS $i q$ is distressed loan indicator that takes the value of one if the price of the loan is less than 80 at week -5 of earnings announcement at quarter $q$ and zero otherwise. COVENANT $T_{i}$ is an indicator variable that equals one if a loan has financial covenant and zero otherwise. $S E C U R E D_{i}$ equals one if a loan is secured and zero otherwise. $M A T U_{i}$ measures the maturity of the loan in terms of the number of years from the loan origination to its maturity. $\operatorname{LOANSIZE}_{i}$ is the size of the loan at its origination, it is expressed in thousands of dollars. $K_{i t}$ is a dummy variable that equal $1 \mathrm{~s}$ if the observed loan return at week $t$ of firm $i$ is in $K$ weeks prior to its quarterly earnings announcement date, and zero otherwise. Regression is repeated for $K=[-5,0]$. Regressions also contain year indicators. T-tests are in the parenthesis below the coefficient, and p-values are calculated using White's standard errors. The superscript asterisks *, **, *** denote significance at or below the $0.10,0.05,0.01$ level, respectively, based on a two-tailed (where sign is not predicted) or a onetailed (where sign is predicted) test of significance. 
Table 4

OLS Regressions of Weekly Syndicated Loan Returns in a Window of [-5,0] Weeks Around Quarterly Earnings Announcement Dates - Intangible vs. Tangible Firms

$$
\begin{aligned}
\text { Model: } R_{i t}= & \alpha+\beta_{1} \text { MR }_{t}+\beta_{2} \text { CE }_{i q}+\beta_{3} \text { SIZE }_{i q}+\beta_{4} \text { RATING }_{i}+\beta_{5} \text { LSPREAD }_{i t}+\beta_{6} \text { NOQUOTE }_{i t} \\
& +\beta_{7} \text { DISTRESS }_{i t}+\beta_{8} \text { COVENANT }_{i}+\beta_{9} \text { SECURED }_{i}+\beta_{10} \text { MATU }_{i}+\beta_{11} \text { LOANSIZE }_{i} \\
& +\beta_{12} K_{i t}+\varepsilon_{i t}
\end{aligned}
$$

\begin{tabular}{|c|c|c|c|c|c|c|c|}
\hline & $\begin{array}{l}\text { Predicted } \\
\text { Sign }\end{array}$ & (1) & (2) & (3) & (4) & (5) & (6) \\
\hline MR & + & $\begin{array}{l}0.0273 \\
(1.68)^{*}\end{array}$ & $\begin{array}{l}0.0293 \\
(1.81)^{*}\end{array}$ & $\begin{array}{l}0.0321 \\
(1.94)^{*}\end{array}$ & $\begin{array}{l}0.0264 \\
(1.62)\end{array}$ & $\begin{array}{l}0.0278 \\
(1.71)^{*}\end{array}$ & $\begin{array}{l}0.0264 \\
(1.62)\end{array}$ \\
\hline $\begin{array}{l}\text { Percentage Change in } \\
\text { Earnings }\end{array}$ & + & $\begin{array}{l}0.0001 \\
(2.01)^{* *}\end{array}$ & $\begin{array}{l}0.0001 \\
(2.03)^{* *}\end{array}$ & $\begin{array}{l}0.0001 \\
(1.86)^{*}\end{array}$ & $\begin{array}{l}0.0001 \\
(2.01)^{* *}\end{array}$ & $\begin{array}{l}0.0001 \\
(2.01)^{* *}\end{array}$ & $\begin{array}{l}0.0001 \\
(2.01)^{* *}\end{array}$ \\
\hline Log of Firm Size & $?$ & $\begin{array}{l}0.0000 \\
(0.10)\end{array}$ & $\begin{array}{l}0.0000 \\
(0.09)\end{array}$ & $\begin{array}{l}0.0000 \\
(0.15)\end{array}$ & $\begin{array}{l}0.0000 \\
(0.12)\end{array}$ & $\begin{array}{l}0.0000 \\
(0.12)\end{array}$ & $\begin{array}{l}0.0000 \\
(0.13)\end{array}$ \\
\hline Loan Rate & - & $\begin{array}{l}-0.0013 \\
(-4.14)^{* * *}\end{array}$ & $\begin{array}{l}-0.0013 \\
(-4.11)^{* * *}\end{array}$ & $\begin{array}{l}-0.0013 \\
(-4.11)^{* * *}\end{array}$ & $\begin{array}{l}-0.0013 \\
(-4.17)^{* * *}\end{array}$ & $\begin{array}{l}-0.0013 \\
(-4.17)^{* * *}\end{array}$ & $\begin{array}{l}-0.0013 \\
(-4.14)^{* * *}\end{array}$ \\
\hline $\begin{array}{l}\text { Log of All-In Spread } \\
\text { (Basis Points over } \\
\text { LIBOR) }\end{array}$ & $?$ & $\begin{array}{l}0.0012 \\
(2.02)^{* *}\end{array}$ & $\begin{array}{l}0.0012 \\
(1.99)^{* *}\end{array}$ & $\begin{array}{l}0.0011 \\
(1.83)^{*}\end{array}$ & $\begin{array}{l}0.0012 \\
(2.02)^{* *}\end{array}$ & $\begin{array}{l}0.0012 \\
(2.03)^{* *}\end{array}$ & $\begin{array}{l}0.0012 \\
(2.02)^{* *}\end{array}$ \\
\hline $\begin{array}{l}\text { Log of Number of } \\
\text { Quotes }\end{array}$ & - & $\begin{array}{l}-0.0010 \\
(-2.24)^{* *}\end{array}$ & $\begin{array}{l}-0.0010 \\
(-2.29)^{* *}\end{array}$ & $\begin{array}{l}-0.0011 \\
(-2.39)^{* *}\end{array}$ & $\begin{array}{l}-0.0010 \\
(-2.23)^{* *}\end{array}$ & $\begin{array}{l}-0.0010 \\
(-2.24)^{* *}\end{array}$ & $\begin{array}{l}-0.0010 \\
(-2.26)^{* *}\end{array}$ \\
\hline $\begin{array}{l}\text { Distressed Loan } \\
\text { Indicator }\end{array}$ & - & $\begin{array}{l}-0.0007 \\
(-1.45)\end{array}$ & $\begin{array}{l}-0.0007 \\
(-1.41)\end{array}$ & $\begin{array}{l}-0.0010 \\
(-1.96)^{*}\end{array}$ & $\begin{array}{l}-0.0007 \\
(-1.38)\end{array}$ & $\begin{array}{l}-0.0007 \\
(-1.37)\end{array}$ & $\begin{array}{l}-0.0007 \\
(-1.38)\end{array}$ \\
\hline $\begin{array}{l}\text { Financial Covenants } \\
\text { Indicator }\end{array}$ & - & $\begin{array}{l}0.0053 \\
(3.52)^{* * *}\end{array}$ & $\begin{array}{l}0.0053 \\
(3.55)^{* * *}\end{array}$ & $\begin{array}{l}0.0052 \\
(3.41)^{* * *}\end{array}$ & $\begin{array}{l}0.0053 \\
(3.53)^{* * *}\end{array}$ & $\begin{array}{l}0.0053 \\
(3.53)^{* * *}\end{array}$ & $\begin{array}{l}0.0054 \\
(3.56)^{* * *}\end{array}$ \\
\hline $\begin{array}{l}\text { Secured Loan } \\
\text { Indicator }\end{array}$ & + & $\begin{array}{l}0.0004 \\
(0.28)\end{array}$ & $\begin{array}{l}0.0004 \\
(0.28)\end{array}$ & $\begin{array}{l}0.0000 \\
(0.02)\end{array}$ & $\begin{array}{l}0.0004 \\
(0.27)\end{array}$ & $\begin{array}{l}0.0004 \\
(0.27)\end{array}$ & $\begin{array}{l}0.0004 \\
(0.27)\end{array}$ \\
\hline $\begin{array}{l}\text { Log of Maturity in } \\
\text { Years }\end{array}$ & + & $\begin{array}{l}-0.0000 \\
(-0.03)\end{array}$ & $\begin{array}{l}-0.0000 \\
(-0.01)\end{array}$ & $\begin{array}{l}-0.0003 \\
(-0.28)\end{array}$ & $\begin{array}{l}-0.0001 \\
(-0.05)\end{array}$ & $\begin{array}{l}-0.0001 \\
(-0.05)\end{array}$ & $\begin{array}{l}-0.0001 \\
(-0.06)\end{array}$ \\
\hline Log of Loan Size & - & $\begin{array}{l}-0.0002 \\
(-0.50)\end{array}$ & $\begin{array}{l}-0.0002 \\
(-0.50)\end{array}$ & $\begin{array}{l}-0.0002 \\
(-0.49)\end{array}$ & $\begin{array}{l}-0.0002 \\
(-0.50)\end{array}$ & $\begin{array}{l}-0.0002 \\
(-0.51)\end{array}$ & $\begin{array}{l}-0.0002 \\
(-0.51)\end{array}$ \\
\hline Week -5 & - & $\begin{array}{l}-0.0007 \\
(-0.90)\end{array}$ & & & & & \\
\hline Week -4 & - & & $\begin{array}{l}-0.0028 \\
(-3.67)^{* * *}\end{array}$ & & & & \\
\hline Week -3 & - & & & $\begin{array}{l}-0.0021 \\
(-2.82)^{* * *}\end{array}$ & & & \\
\hline Week -2 & - & & & & $\begin{array}{l}-0.0010 \\
(-1.47)\end{array}$ & & \\
\hline Week -1 & - & & & & & $\begin{array}{l}-0.0006 \\
(-0.80)\end{array}$ & \\
\hline Week 0 & - & & & & & & $\begin{array}{l}0.0013 \\
(0.69)\end{array}$ \\
\hline Observations & & 1798 & 1798 & 1798 & 1798 & 1798 & 1798 \\
\hline Adjusted $\mathrm{R}^{2}$ & & 0.0476 & 0.0544 & 0.0520 & 0.0483 & 0.0475 & 0.0490 \\
\hline
\end{tabular}

Panel A: Bad news and intangible firms 
Panel B: Bad news and tangible firms

\begin{tabular}{|c|c|c|c|c|c|c|c|}
\hline & $\begin{array}{l}\text { Predicted } \\
\text { Sign }\end{array}$ & (1) & (2) & (3) & (4) & (5) & (6) \\
\hline MR & + & $\begin{array}{l}0.0023 \\
(0.38)\end{array}$ & $\begin{array}{l}0.0017 \\
(0.27)\end{array}$ & $\begin{array}{l}0.0016 \\
(0.27)\end{array}$ & $\begin{array}{l}0.0016 \\
(0.27)\end{array}$ & $\begin{array}{l}0.0018 \\
(0.29)\end{array}$ & $\begin{array}{l}0.0016 \\
(0.26)\end{array}$ \\
\hline $\begin{array}{l}\text { Percentage Change in } \\
\text { Earnings }\end{array}$ & + & $\begin{array}{l}0.0000 \\
(0.07)\end{array}$ & $\begin{array}{l}0.0000 \\
(0.05)\end{array}$ & $\begin{array}{l}0.0000 \\
(0.03)\end{array}$ & $\begin{array}{l}0.0000 \\
(0.04)\end{array}$ & $\begin{array}{l}0.0000 \\
(0.04)\end{array}$ & $\begin{array}{l}0.0000 \\
(0.02)\end{array}$ \\
\hline Log of Firm Size & $?$ & $\begin{array}{l}-0.0001 \\
(-1.39)\end{array}$ & $\begin{array}{l}-0.0001 \\
(-1.43)\end{array}$ & $\begin{array}{l}-0.0001 \\
(-1.48)\end{array}$ & $\begin{array}{l}-0.0001 \\
(-1.48)\end{array}$ & $\begin{array}{l}-0.0001 \\
(-1.49)\end{array}$ & $\begin{array}{l}-0.0001 \\
(-1.48)\end{array}$ \\
\hline Loan Rate & - & $\begin{array}{l}-0.0000 \\
(-0.20)\end{array}$ & $\begin{array}{l}-0.0000 \\
(-0.08)\end{array}$ & $\begin{array}{l}-0.0000 \\
(-0.13)\end{array}$ & $\begin{array}{l}-0.0000 \\
(-0.13)\end{array}$ & $\begin{array}{l}-0.0000 \\
(-0.13)\end{array}$ & $\begin{array}{l}-0.0000 \\
(-0.13)\end{array}$ \\
\hline $\begin{array}{l}\text { Log of All-In Spread } \\
\text { (Basis Points over } \\
\text { LIBOR) }\end{array}$ & $?$ & $\begin{array}{l}-0.0006 \\
(-2.57)^{* *}\end{array}$ & $\begin{array}{l}-0.0005 \\
(-2.06)^{* *}\end{array}$ & $\begin{array}{l}-0.0006 \\
(-2.53)^{* *}\end{array}$ & $\begin{array}{l}-0.0006 \\
(-2.53)^{* *}\end{array}$ & $\begin{array}{l}-0.0006 \\
(-2.53)^{* *}\end{array}$ & $\begin{array}{l}-0.0005 \\
(-2.52)^{* *}\end{array}$ \\
\hline $\begin{array}{l}\text { Log of Number of } \\
\text { Quotes }\end{array}$ & - & $\begin{array}{l}-0.0004 \\
(-2.65)^{* *}\end{array}$ & $\begin{array}{l}-0.0004 \\
(-2.45)^{* *}\end{array}$ & $\begin{array}{l}-0.0005 \\
(-2.69)^{* *}\end{array}$ & $\begin{array}{l}-0.0005 \\
(-2.68)^{* *}\end{array}$ & $\begin{array}{l}-0.0005 \\
(-2.68)^{* *}\end{array}$ & $\begin{array}{l}-0.0004 \\
(-2.68)^{* *}\end{array}$ \\
\hline $\begin{array}{l}\text { Distressed Loan } \\
\text { Indicator }\end{array}$ & - & $\begin{array}{l}0.0000 \\
(0.18)\end{array}$ & $\begin{array}{l}0.0000 \\
(0.23)\end{array}$ & $\begin{array}{l}0.0001 \\
(0.53)\end{array}$ & $\begin{array}{l}0.0001 \\
(0.52)\end{array}$ & $\begin{array}{l}0.0001 \\
(0.53)\end{array}$ & $\begin{array}{l}0.0000 \\
(0.51)\end{array}$ \\
\hline $\begin{array}{l}\text { Financial Covenants } \\
\text { Indicator }\end{array}$ & - & $\begin{array}{l}-0.0004 \\
(-1.85)^{*}\end{array}$ & $\begin{array}{l}-0.0003 \\
(-1.68)^{*}\end{array}$ & $\begin{array}{l}-0.0004 \\
(-1.86)^{*}\end{array}$ & $\begin{array}{l}-0.0004 \\
(-1.85)^{*}\end{array}$ & $\begin{array}{l}-0.0004 \\
(-1.85)^{*}\end{array}$ & $\begin{array}{l}-0.0004 \\
(-1.85)^{*}\end{array}$ \\
\hline $\begin{array}{l}\text { Secured Loan } \\
\text { Indicator }\end{array}$ & + & $\begin{array}{l}0.0004 \\
(1.08)\end{array}$ & $\begin{array}{l}0.0003 \\
(0.93)\end{array}$ & $\begin{array}{l}0.0003 \\
(1.06)\end{array}$ & $\begin{array}{l}0.0003 \\
(1.06)\end{array}$ & $\begin{array}{l}0.0003 \\
(1.06)\end{array}$ & $\begin{array}{l}0.0003 \\
(1.05)\end{array}$ \\
\hline $\begin{array}{l}\text { Log of Maturity in } \\
\text { Years }\end{array}$ & + & $\begin{array}{l}0.0008 \\
(2.93)^{* * *}\end{array}$ & $\begin{array}{l}0.0007 \\
(2.85)^{* * *}\end{array}$ & $\begin{array}{l}0.0008 \\
(2.98)^{* * *}\end{array}$ & $\begin{array}{l}0.0008 \\
(2.97)^{* * *}\end{array}$ & $\begin{array}{l}0.0008 \\
(2.97)^{* * *}\end{array}$ & $\begin{array}{l}0.0008 \\
(2.97)^{* * *}\end{array}$ \\
\hline Log of Loan Size & - & $\begin{array}{l}-0.0001 \\
(-0.79)\end{array}$ & $\begin{array}{l}-0.0001 \\
(-0.88)\end{array}$ & $\begin{array}{l}-0.0001 \\
(-0.82)\end{array}$ & $\begin{array}{l}-0.0001 \\
(-0.82)\end{array}$ & $\begin{array}{l}-0.0001 \\
(-0.82)\end{array}$ & $\begin{array}{l}-0.0001 \\
(-0.83)\end{array}$ \\
\hline Week -5 & - & $\begin{array}{l}-0.0003 \\
(-1.06)\end{array}$ & & & & & \\
\hline Week -4 & - & & $\begin{array}{l}-0.001 \\
(-1.42)^{* *}\end{array}$ & & & & \\
\hline Week -3 & - & & & $\begin{array}{l}0.0001 \\
(0.49)\end{array}$ & & & \\
\hline Week -2 & - & & & & $\begin{array}{l}-0.0001 \\
(-0.25)\end{array}$ & & \\
\hline Week -1 & - & & & & & $\begin{array}{l}0.0001 \\
(0.56)\end{array}$ & \\
\hline Week 0 & - & & & & & & $\begin{array}{l}-0.0003 \\
(-1.21)\end{array}$ \\
\hline Observations & & 3233 & 3233 & 3233 & 3233 & 3233 & 3233 \\
\hline Adjusted $\mathrm{R}^{2}$ & & 0.0077 & 0.0074 & 0.0078 & 0.0077 & 0.0078 & 0.0081 \\
\hline
\end{tabular}


Panel C: Good news and intangible firms

\begin{tabular}{|c|c|c|c|c|c|c|c|}
\hline & $\begin{array}{l}\text { Predicted } \\
\text { Sign }\end{array}$ & (1) & (2) & (3) & (4) & (5) & (6) \\
\hline MR & + & $\begin{array}{l}0.0321 \\
(1.43)\end{array}$ & $\begin{array}{l}0.0325 \\
(1.45)\end{array}$ & $\begin{array}{l}0.0318 \\
(1.41)\end{array}$ & $\begin{array}{l}0.0341 \\
(1.52)\end{array}$ & $\begin{array}{l}0.0317 \\
(1.41)\end{array}$ & $\begin{array}{l}0.0320 \\
(1.42)\end{array}$ \\
\hline $\begin{array}{l}\text { Percentage Change in } \\
\text { Earnings }\end{array}$ & + & $\begin{array}{l}0.0000 \\
(0.04)\end{array}$ & $\begin{array}{l}0.0000 \\
(0.06)\end{array}$ & $\begin{array}{l}0.0000 \\
(0.05)\end{array}$ & $\begin{array}{l}0.0000 \\
(0.06)\end{array}$ & $\begin{array}{l}0.0000 \\
(0.05)\end{array}$ & $\begin{array}{l}0.0000 \\
(0.05)\end{array}$ \\
\hline Log of Firm Size & $?$ & $\begin{array}{l}-0.0001 \\
(-0.90)\end{array}$ & $\begin{array}{l}-0.0001 \\
(-0.90)\end{array}$ & $\begin{array}{l}-0.0001 \\
(-0.92)\end{array}$ & $\begin{array}{l}-0.0001 \\
(-0.91)\end{array}$ & $\begin{array}{l}-0.0001 \\
(-0.91)\end{array}$ & $\begin{array}{l}-0.0001 \\
(-0.91)\end{array}$ \\
\hline Loan Rate & - & $\begin{array}{l}-0.0005 \\
(-1.41)\end{array}$ & $\begin{array}{l}-0.0005 \\
(-1.40)\end{array}$ & $\begin{array}{l}-0.0005 \\
(-1.44)\end{array}$ & $\begin{array}{l}-0.0005 \\
(-1.40)\end{array}$ & $\begin{array}{l}-0.0005 \\
(-1.43)\end{array}$ & $\begin{array}{l}-0.0005 \\
(-1.43)\end{array}$ \\
\hline $\begin{array}{l}\text { Log of All-In Spread } \\
\text { (Basis Points over } \\
\text { LIBOR) }\end{array}$ & $?$ & $\begin{array}{l}-0.0003 \\
(-0.49)\end{array}$ & $\begin{array}{l}-0.0003 \\
(-0.50)\end{array}$ & $\begin{array}{l}-0.0003 \\
(-0.49)\end{array}$ & $\begin{array}{l}-0.0003 \\
(-0.48)\end{array}$ & $\begin{array}{l}-0.0003 \\
(-0.49)\end{array}$ & $\begin{array}{l}-0.0003 \\
(-0.50)\end{array}$ \\
\hline $\begin{array}{l}\text { Log of Number of } \\
\text { Quotes }\end{array}$ & - & $\begin{array}{l}-0.0005 \\
(-0.92)\end{array}$ & $\begin{array}{l}-0.0005 \\
(-0.92)\end{array}$ & $\begin{array}{l}-0.0005 \\
(-0.93)\end{array}$ & $\begin{array}{l}-0.0005 \\
(-0.92)\end{array}$ & $\begin{array}{l}-0.0005 \\
(-0.92)\end{array}$ & $\begin{array}{l}-0.0005 \\
(-0.92)\end{array}$ \\
\hline $\begin{array}{l}\text { Distressed Loan } \\
\text { Indicator }\end{array}$ & - & $\begin{array}{l}0.0004 \\
(0.66)\end{array}$ & $\begin{array}{l}0.0005 \\
(0.69)\end{array}$ & $\begin{array}{l}0.0005 \\
(0.74)\end{array}$ & $\begin{array}{l}0.0005 \\
(0.70)\end{array}$ & $\begin{array}{l}0.0005 \\
(0.74)\end{array}$ & $\begin{array}{l}0.0005 \\
(0.74)\end{array}$ \\
\hline $\begin{array}{l}\text { Financial Covenants } \\
\text { Indicator }\end{array}$ & + & $\begin{array}{l}-0.0008 \\
(-0.60)\end{array}$ & $\begin{array}{l}-0.0008 \\
(-0.61)\end{array}$ & $\begin{array}{l}-0.0008 \\
(-0.60)\end{array}$ & $\begin{array}{l}-0.0008 \\
(-0.61)\end{array}$ & $\begin{array}{l}-0.0008 \\
(-0.60)\end{array}$ & $\begin{array}{l}-0.0008 \\
(-0.60)\end{array}$ \\
\hline $\begin{array}{l}\text { Secured Loan } \\
\text { Indicator }\end{array}$ & + & $\begin{array}{l}0.0018 \\
(1.08)\end{array}$ & $\begin{array}{l}0.0018 \\
(1.08)\end{array}$ & $\begin{array}{l}0.0018 \\
(1.09)\end{array}$ & $\begin{array}{l}0.0018 \\
(1.07)\end{array}$ & $\begin{array}{l}0.0018 \\
(1.07)\end{array}$ & $\begin{array}{l}0.0018 \\
(1.08)\end{array}$ \\
\hline $\begin{array}{l}\text { Log of Maturity in } \\
\text { Years }\end{array}$ & + & $\begin{array}{l}0.0000 \\
(0.01)\end{array}$ & $\begin{array}{l}0.0000 \\
(0.01)\end{array}$ & $\begin{array}{l}0.0000 \\
(0.00)\end{array}$ & $\begin{array}{l}0.0000 \\
(0.01)\end{array}$ & $\begin{array}{l}0.0000 \\
(0.01)\end{array}$ & $\begin{array}{l}0.0000 \\
(0.01)\end{array}$ \\
\hline Log of Loan Size & - & $\begin{array}{l}-0.0001 \\
(-0.25)\end{array}$ & $\begin{array}{l}-0.0001 \\
(-0.25)\end{array}$ & $\begin{array}{l}-0.0001 \\
(-0.25)\end{array}$ & $\begin{array}{l}-0.0001 \\
(-0.24)\end{array}$ & $\begin{array}{l}-0.0001 \\
(-0.26)\end{array}$ & $\begin{array}{l}-0.0001 \\
(-0.25)\end{array}$ \\
\hline Week -5 & + & $\begin{array}{l}-0.0009 \\
(-0.99)\end{array}$ & & & & & \\
\hline Week -4 & + & & $\begin{array}{l}-0.0017 \\
(-1.36)\end{array}$ & & & & \\
\hline Week -3 & + & & & $\begin{array}{l}0.0006 \\
(0.70)\end{array}$ & & & \\
\hline Week -2 & + & & & & $\begin{array}{l}-0.0026 \\
(-1.00)\end{array}$ & & \\
\hline Week -1 & + & & & & & $\begin{array}{l}0.0003 \\
(0.32)\end{array}$ & \\
\hline Week 0 & + & & & & & & $\begin{array}{l}0.0004 \\
(0.42)\end{array}$ \\
\hline Observations & & 1646 & 1646 & 1646 & 1646 & 1646 & 1646 \\
\hline Adjusted $\mathrm{R}^{2}$ & & 0.0003 & 0.0004 & 0.0003 & 0.0003 & 0.0003 & 0.0003 \\
\hline
\end{tabular}


Panel D: Good news and tangible firms

\begin{tabular}{|c|c|c|c|c|c|c|c|}
\hline & $\begin{array}{l}\text { Predicted } \\
\text { Sign }\end{array}$ & (1) & (2) & (3) & (4) & (5) & (6) \\
\hline MR & + & $\begin{array}{l}0.0109 \\
(0.91)\end{array}$ & $\begin{array}{l}0.0097 \\
(0.82)\end{array}$ & $\begin{array}{l}0.0107 \\
(0.90)\end{array}$ & $\begin{array}{l}0.0108 \\
(0.91)\end{array}$ & $\begin{array}{l}0.0108 \\
(0.91)\end{array}$ & $\begin{array}{l}0.0108 \\
(0.91)\end{array}$ \\
\hline $\begin{array}{l}\text { Percentage Change in } \\
\text { Earnings }\end{array}$ & + & $\begin{array}{l}0.0000 \\
(0.23)\end{array}$ & $\begin{array}{l}0.0000 \\
(0.21)\end{array}$ & $\begin{array}{l}0.0000 \\
(0.23)\end{array}$ & $\begin{array}{l}0.0000 \\
(0.23)\end{array}$ & $\begin{array}{l}0.0000 \\
(0.23)\end{array}$ & $\begin{array}{l}0.0000 \\
(0.23)\end{array}$ \\
\hline Log of Firm Size & $?$ & $\begin{array}{l}0.0004 \\
(2.35)^{* *}\end{array}$ & $\begin{array}{l}0.0004 \\
(2.35)^{* *}\end{array}$ & $\begin{array}{l}0.0004 \\
(2.35)^{* *}\end{array}$ & $\begin{array}{l}0.0004 \\
(2.35)^{* *}\end{array}$ & $\begin{array}{l}0.0004 \\
(2.35)^{* *}\end{array}$ & $\begin{array}{l}0.0004 \\
(2.35)^{* *}\end{array}$ \\
\hline Loan Rate & - & $\begin{array}{l}-0.0003 \\
(-1.62)\end{array}$ & $\begin{array}{l}-0.0003 \\
(-1.62)\end{array}$ & $\begin{array}{l}-0.0003 \\
(-1.63)\end{array}$ & $\begin{array}{l}-0.0003 \\
(-1.62)\end{array}$ & $\begin{array}{l}-0.0003 \\
(-1.62)\end{array}$ & $\begin{array}{l}-0.0003 \\
(-1.62)\end{array}$ \\
\hline $\begin{array}{l}\text { Log of All-In Spread } \\
\text { (Basis Points over } \\
\text { LIBOR) }\end{array}$ & $?$ & $\begin{array}{l}0.0003 \\
(0.51)\end{array}$ & $\begin{array}{l}0.0003 \\
(0.51)\end{array}$ & $\begin{array}{l}0.0003 \\
(0.52)\end{array}$ & $\begin{array}{l}0.0003 \\
(0.51)\end{array}$ & $\begin{array}{l}0.0003 \\
(0.51)\end{array}$ & $\begin{array}{l}0.0003 \\
(0.51)\end{array}$ \\
\hline $\begin{array}{l}\text { Log of Number of } \\
\text { Quotes }\end{array}$ & - & $\begin{array}{l}-0.0005 \\
(-1.93)^{*}\end{array}$ & $\begin{array}{l}-0.0006 \\
(-1.95)^{*}\end{array}$ & $\begin{array}{l}-0.0006 \\
(-1.94)^{*}\end{array}$ & $\begin{array}{l}-0.0006 \\
(-1.94)^{*}\end{array}$ & $\begin{array}{l}-0.0006 \\
(-1.93)^{*}\end{array}$ & $\begin{array}{l}-0.0006 \\
(-1.93)^{*}\end{array}$ \\
\hline $\begin{array}{l}\text { Distressed Loan } \\
\text { Indicator }\end{array}$ & - & $\begin{array}{l}-0.0013 \\
(-3.28)^{* * *}\end{array}$ & $\begin{array}{l}-0.0014 \\
(-3.48)^{* * *}\end{array}$ & $\begin{array}{l}-0.0013 \\
(-3.33)^{* * *}\end{array}$ & $\begin{array}{l}-0.0013 \\
(-3.33)^{* * *}\end{array}$ & $\begin{array}{l}-0.0013 \\
(-3.34)^{* * *}\end{array}$ & $\begin{array}{l}-0.0013 \\
(-3.34)^{* * *}\end{array}$ \\
\hline $\begin{array}{l}\text { Financial Covenants } \\
\text { Indicator }\end{array}$ & + & $\begin{array}{l}0.0007 \\
(1.76)^{*}\end{array}$ & $\begin{array}{l}0.0007 \\
(1.77)^{*}\end{array}$ & $\begin{array}{l}0.0007 \\
(1.76)^{*}\end{array}$ & $\begin{array}{l}0.0007 \\
(1.76)^{*}\end{array}$ & $\begin{array}{l}0.0007 \\
(1.76)^{*}\end{array}$ & $\begin{array}{l}0.0007 \\
(1.76)^{*}\end{array}$ \\
\hline $\begin{array}{l}\text { Secured Loan } \\
\text { Indicator }\end{array}$ & + & $\begin{array}{l}0.0012 \\
(1.90)^{*}\end{array}$ & $\begin{array}{l}0.0013 \\
(1.90)^{*}\end{array}$ & $\begin{array}{l}0.0012 \\
(1.90)^{*}\end{array}$ & $\begin{array}{l}0.0013 \\
(1.90)^{*}\end{array}$ & $\begin{array}{l}0.0013 \\
(1.90)^{*}\end{array}$ & $\begin{array}{l}0.0013 \\
(1.90)^{*}\end{array}$ \\
\hline $\begin{array}{l}\text { Log of Maturity in } \\
\text { Years }\end{array}$ & + & $\begin{array}{l}0.0010 \\
(1.90)^{*}\end{array}$ & $\begin{array}{l}0.0011 \\
(1.92)^{*}\end{array}$ & $\begin{array}{l}0.0010 \\
(1.90)^{*}\end{array}$ & $\begin{array}{l}0.0010 \\
(1.91)^{*}\end{array}$ & $\begin{array}{l}0.0010 \\
(1.91)^{*}\end{array}$ & $\begin{array}{l}0.0010 \\
(1.91)^{*}\end{array}$ \\
\hline Log of Loan Size & - & $\begin{array}{l}-0.0005 \\
(-2.02)^{* * *}\end{array}$ & $\begin{array}{l}-0.0005 \\
(-2.02)^{* * *}\end{array}$ & $\begin{array}{l}-0.0005 \\
(-2.01)^{* * *}\end{array}$ & $\begin{array}{l}-0.0005 \\
(-2.01)^{* * *}\end{array}$ & $\begin{array}{l}-0.0005 \\
(-2.02)^{* * *}\end{array}$ & $\begin{array}{l}-0.0005 \\
(-2.02)^{* * *}\end{array}$ \\
\hline Week -5 & + & $\begin{array}{l}0.0002 \\
(0.36)\end{array}$ & & & & & \\
\hline Week -4 & + & & $\begin{array}{l}-0.014 \\
(-1.60)\end{array}$ & & & & \\
\hline Week -3 & + & & & $\begin{array}{l}0.0003 \\
(0.66)\end{array}$ & & & \\
\hline Week -2 & + & & & & $\begin{array}{l}0.0002 \\
(0.41)\end{array}$ & & \\
\hline Week -1 & + & & & & & $\begin{array}{l}0.0000 \\
(0.07)\end{array}$ & \\
\hline Week 0 & + & & & & & & $\begin{array}{l}0.0001 \\
(0.23)\end{array}$ \\
\hline Observations & & 4357 & 4357 & 4357 & 4357 & 4357 & 4357 \\
\hline Adjusted $\mathrm{R}^{2}$ & & 0.0131 & 0.0147 & 0.0132 & 0.0131 & 0.0131 & 0.0131 \\
\hline
\end{tabular}

Notes: This table reports regression results for testing the information content of quarterly earnings on syndicated loan returns using pooled cross-sectional, time-series ordinary least squares for bad/good news and intangible, bad/good news and tangible firms over -5 to 0 weeks of each quarterly earnings announcement during 1998-2002 period, respectively. Good/Bad news firms are defined as whether change in quarterly earnings for the same quarter from year $t-1$ to year $t$ is no less than/less than zero. Intangible/tangible is classified by whether the firm is in an intangible-intensive industry or not. $R_{i t}$ is the weekly return on syndicated loan facility $i$ in week $t . M R_{t}$ is return on S\&P syndicated loan index in week t. $C E_{i q}$ is the percentage change in quarterly earnings measured by changes in earnings for quarter $q$ from the current year to the prior year for firm $i$. SIZE $E_{i q}$ is firm size, measured by the market capitalization (in millions of dollars)at the beginning of quarter $q$ for firm $i . R_{A T I N G_{i}}$ is an indicator variable coded into 1 through 7 to represent Moody's senior debt ratings of Aaa, Aa, A, Baa, Ba, B and lower than B on facility i. SPREAD $D_{i t}$ is all-in spread, measured by the basis point spread over LIBOR, inclusive of all fees for 
facility $i$ at week $t$. NOQUOTES $S_{i t}$ is the total number of weekly quotes on facility $i$ at week $t$. DISTRESS $i q$ is distressed loan indicator that takes the value of one if the price of the loan is less than 80 at week -5 of earnings announcement at quarter $q$ and zero otherwise. COVENANT $T_{i}$ is an indicator variable that equals one if a loan has financial covenant and zero otherwise. $S E C U R E D_{i}$ equals one if a loan is secured and zero otherwise. $M A T U_{i}$ measures the maturity of the loan in terms of the number of years from the loan origination to its maturity. $\operatorname{LOANSIZE}_{i}$ is the size of the loan at its origination, it is expressed in thousands of dollars. $K_{i t}$ is a dummy variable that equal $1 \mathrm{~s}$ if the observed loan return at week $t$ of firm $i$ is in $K$ weeks prior to its quarterly earnings announcement date, and zero otherwise. Regression is repeated for $K=[-5,0]$. Regressions also contain year indicators. T-tests are in the parenthesis below the coefficient, and p-values are calculated using White's standard errors. The superscript asterisks $*, * *, * * *$ denotes significance at or below the $0.10,0.05,0.01$ level, respectively, based on a two-tailed (where sign is not predicted) or a onetailed (where sign is predicted) test of significance. 